\title{
The European Union's Potential for Strategic Emissions Trading through Minimal Permit Sale Contracts
}

\author{
Johan Eyckmans \\ Cathrine Hagem
}

\author{
CESIFO WORKING PAPER NO. 2809 \\ CATEGORY 10: ENERGY AND CLIMATE ECONOMICS \\ SEPTEMBER 2009
}
An electronic version of the paper may be downloaded
- from the SSRN website:
- from the RePEc website:
- from the CESifo website:
www.SSRN.com
Www.RePEc.org
www.CESifo-group.org/wp




\title{
The European Union's Potential for Strategic Emissions Trading through Minimal Permit Sale Contracts
}

\begin{abstract}
Strategic market behavior by permit sellers will harm the European Union as the EU as a whole is expected to become a large net buyer of permits in a follow-up agreement to the Kyoto Protocol. In this paper we explore how the EU could benefit from making permit trade agreements with non-EU countries. These trade agreements involve a minimum permit sales requirement complemented by a financial transfer from the EU to the other contract party. Such agreements enable the EU to act strategically in the permit market on behalf of its member states, although each member state is assumed to behave as a price taker in the permit market. Using a stylized numerical simulation model we show that an appropriately designed permit trade agreement between the EU and China can cut EU's total compliance cost significantly. This result is robust for a wide range of parameterizations of the simulation model.
\end{abstract}

JEL Code: Q54.

Keywords: emissions permit, post-Kyoto climate agreement, strategic permit trade.

\author{
Johan Eyckmans \\ Catholic University of Leuven \\ Belgium \\ Johan.Eyckmans@econ.kuleiven.be
}

\author{
Cathrine Hagem \\ Statistics Norway \\ Norway \\ cathrine.hagem@ssb.no
}

The work on this article was initiated during our participation in the project "Environmental economics: policy instruments, technology development, and international cooperation" conducted at the Centre for Advanced Study (CAS) at the Norwegian Academy of Science and Letters in Oslo in 2005/2006. The financial, administrative and professional support of the Centre to this project is much appreciated. Financial support of the Norwegian Research Council is also highly appreciated. Valuable comments by an editor and two anonymous reviewers on an earlier version of this paper are gratefully acknowledged. 


\section{Introduction}

The purpose of this paper is to study the optimal strategy of a group of net buyers of emission permits (for instance the EU) under a future international climate agreement, i.e. a follow-up agreement to the Kyoto Protocol. In 1997, the Kyoto Protocol was signed during the third Conference of the Parties (CoP) of the United Nations Framework Convention on Climate Change (UNFCCC). The 39 signatories of the Protocol, listed in the so-called Annex-B, and representing about two thirds of global emissions in 1990, promised to reduce their emissions of six greenhouse gasses by 5.2 percent compared to 1990 levels by $2008-2012$ (the so-called first commitment period). Each Annex-B country has been allocated an initial amount of emission permits corresponding to their quantitative emissions limits. The permits can be traded with other Annex-B countries. Furthermore, Annex-B countries are allowed to meet part of their reduction commitment through investment in emission-reducing projects in developing countries (the Clean Development Mechanism, CDM), or in other industrialized countries (Joint Implementation, JI). The Protocol does not impose binding emission targets on developing countries signatories ${ }^{1}$. Despite persistent refusal by the USA (and until recently also by Australia) to ratify it, the Kyoto Protocol came into force in 2005.

It is well recognized that there are at least two important shortcomings of the original Kyoto agreement ${ }^{2}$. First, the global emission reduction achieved by the Kyoto Protocol will be very limited $^{3}$. Second, this global emission reduction will not be produced in a cost-efficient manner due to two reasons. First, the number of countries participating is limited meaning that many low-cost abatement options in developing countries cannot be fully exploited, see among others Stewart and Wiener $(2003)^{4}$. Secondly, a number of studies have concluded that Russia, and other former Soviet republics and Eastern European countries, will become large sellers of permits, see: Criqui et al. (1999), Weyant and Hill (1999), Weyant (1999) and Sager (2003). Böhringer (2002) concludes that the Former Soviet Union can significantly increase its benefit of the Kyoto agreement by exploiting its market power in the permit market, which

\footnotetext{
${ }^{1}$ The explanations for the Kyoto protocol's inability to deter free-riding is inter alia given in Barrett (1999).

${ }^{2}$ Another important shortcoming is the lack of incentives for investment in R\&D. This problem is inter alia addressed in Golombek and Hoel (2006).

${ }^{3}$ The share of the ratifying Annex-B countries in global emissions is projected to decrease to about one third by 2012 because of rapidly growing emissions in non-Annex-B countries. The modest global emission reduction achieved by the Kyoto Protocol is, inter alia, discussed in Böhringer (2002), Hagem and Holtsmark (2001), den Elzen and de Moor (2002) and Eyckmans, Van Regemorter and van Steenberghe (2005).

${ }^{4}$ The CDM is a project-based mechanism that cannot ensure that all low cost options can be exploited as there are several abatement options that cannot be attributed to any specific investment project (for instance in the transport sector). See http://unfccc.int/kyoto_protocol/mechanisms/items/1673.php for guidelines to validation of CDM-projects.
} 
implies that marginal abatement cost are not equalized across the participating countries, and the permit price becomes higher than under perfectly competitive permit market conditions. As a result, total emission reduction will be produced at a too high cost compared to the ideal cost efficient burden sharing. Possibly, the prospect of high compliance costs makes countries reluctant to accept ambitious emission reduction targets for a future climate agreement. In the current Kyoto Protocol, the only policy instrument for distributing costs between participants is the initial allocation of tradable permits across countries. As long as burden-sharing considerations are only taken care of through the initial distribution of permits, it is likely that some countries will become large traders and can benefit from exercising market power also in the post-Kyoto emissions permits market ${ }^{5}$. Furthermore, if a future follow-up agreement does not specify any minimal levels of some particular domestic climate policy instruments, as was the case under the original Kyoto Protocol, governments can act strategically in the international permit market by steering their domestic emission levels through domestic taxes/domestic permits or direct regulations.

Strategic permit trade among permit seller will harm the European Union as a group. The EU as a group is expected to become a large net buyer of permits in a follow-up agreement to the Kyoto protocol as EU have announced repeatedly their willingness to accept though emissions ceilings. Our analysis will focus on the possible strategies of the European Union as a group of net buyers of permits, although each individual EU country is assumed to act as a competitive price-taking agent in the permit market ${ }^{6}$. The EU countries are obvious candidates for cooperation in the permit market as they presently cooperate on their climate policy, and have established an internal emission trading scheme (the Emission Trading Scheme ETS). The EU countries have also shown already their willingness to cooperate on net permit demand by determining the degree to which their emission target is to be met by domestic reduction measures relative to permit purchases (the so-called supplementary debate in the context of climate policy). ${ }^{7}$ Furthermore, the EU has established a common target for

\footnotetext{
${ }^{5}$ Hahn (1984) shows that opportunities for an agent to exercise market power could be undermined (i.e., the cost-effective outcome is achieved) by the appropriate distribution of permits between agents. However, burdensharing considerations may prevent a distribution of permits that undermines market power.

${ }^{6}$ Since 2005, the EU has its own internal industry carbon emissions trading scheme, and thus, at the time being, it is not obvious that there will be trade in emission permits across countries participating and non-participating in EU's trading scheme. However, the starting point for this paper is that all permits assigned by a future climate agreement are fully tradable and accepted by all countries. We assume that in a Kyoto follow-up agreement after 2012, the EU does not deny its member states the right to meet their obligations by permits purchased from other countries participating in the agreement.

${ }^{7}$ The EU Commission did not accept national allocation plans for the EU ETS for 2008-12, if there were no restrictions on the amount of emission credits they could buy from non-EU countries. See Neuhoff et al. (2006).
} 
their emissions several years ahead, in particular for the year 2020. We therefore find it reasonable to assume that the EU will take the lead in establishing possible future agreements with other countries regarding emissions trading for the post-Kyoto period.

We show in this paper that the EU can benefit from making appropriately designed bilateral permit trade agreements with large strategic sellers of emissions permits, either genuine participants in the emissions trading, or large suppliers of project-based emission reductions like under the CDM in the current Kyoto Protocol. Such bilateral agreements should specify a minimum amount of permits that the other countries should sell in the market and it enables the EU to act strategically on behalf of its member states.

The permit trade agreements can therefore be interpreted as a way for the EU to exercise market power. Similar ideas where put forward by Ellerman and Wing (2000) in the framework of the supplementarity discussion in the aftermath of the signing of the 1997 Kyoto Protocol. However, Ellerman and Wing (2000) consider the case where the EU exercises market power on the demand side of the permit market (through the supplementary requirement that a particular fraction of a country's obligation is to be met by domestic emission reduction), whereas we consider the case where the EU exercises market power on the supply side of the market (through bilateral contracts with major permit exporters). Our work relates also to the paper by Bernard et al. (2008) who model the impact of the entry of China in the international permit market on market power of Russia. Our approach differs however, because we allow for strategic contracts to be made by EU with new entrants in order to influence the market outcome.

The Kyoto Protocol allows for emissions trading as a means of meeting a country's obligations. The contracts discussed in this paper can bee seen as an emission trading arrangement, where one party (the EU) pays another country for implementing a minimum amount of abatement measures, and where the country sells the subsequent excess emission permits (or generated CDM-credits) on the international market. Hence, legally speaking, the type of bilateral contract we consider in this paper is not against the spirit of the UN Framework Convention on Climate Change or the 1997 Kyoto Protocol.

In order to investigate the possibility for bilateral contracts we consider first a stylized theoretical model of the international permit market. We model the situation as a two-stage game. In the first stage the EU offers a trade contract to one or several other countries. In the 
second stage, international permit trade occurs, possibly involving strategic behaviour by some major permit exporters. Secondly, we turn to a stylized numerical simulation model of the international permit market in order to quantify the impact of bilateral agreements on the equilibrium permit price and regional welfare levels.

The rest of the paper is organized as follows. In the section 2 we describe the climate agreement. In section 3 we first characterize emission behavior by price-taking market participants (section 3.1) and then turn to non-competitive market behavior (section 3.2) in the absence of permit trade contracts. In section 4, we consider a situation where the EU takes an initiative to offer trade contracts to one or several other participants prior to the beginning of the trading period (post-Kyoto period). We characterize the optimal contract design and the optimal choice of contract partners. A numerical illustration of our model is given in section 5. Section 6 summarizes our main findings.

\section{A future climate agreement}

Let $\mathrm{K}=\{1,2, \ldots, \mathrm{k}\}$ denote the countries participating in a follow-up climate agreement to the Kyoto Protocol. Let $e_{i} \in\left[0, e_{i}^{B A U}\right]$ denote actual emissions from an individual country $i$ and let $\varepsilon_{\mathrm{K}}$ denote the constraint on total emissions of all countries participating in the future climate agreement. The total emissions constraint for the agreement members is therefore given by:

$$
\sum_{i \in K} e_{i} \leq \varepsilon_{K}
$$

We henceforth assume that (1) is satisfied with equality. A system of tradable emissions permits is implemented among the members of the agreement and permits are grandfathered, i.e. given for free to the participants. Let $\left(\varepsilon_{1}, \varepsilon_{2}, \ldots, \varepsilon_{\mathrm{k}}\right)$ denote the distribution of emission permits which should satisfy the group's total emissions constraint:

$$
\sum_{i \in \mathrm{K}} \varepsilon_{\mathrm{i}}=\varepsilon_{\mathrm{K}}
$$

In the absence of any cooperation across countries, the net benefits of emissions (welfare, $\mathrm{W}$ ) of the members of the Kyoto follow up climate agreement are given by: 


$$
\mathrm{W}_{\mathrm{i}}=\mathrm{B}_{\mathrm{i}}\left(\mathrm{e}_{\mathrm{i}}\right)+\mathrm{p} \cdot\left[\varepsilon_{\mathrm{i}}-\mathrm{e}_{\mathrm{i}}\right] \quad \mathrm{i} \in \mathrm{K}
$$

where $B_{i}\left(e_{i}\right)$ denotes the benefits of emissions function and $p$ is the market price of emissions permits. We assume that the benefits functions are increasing and strictly concave: $\mathrm{B}_{\mathrm{i}}^{\prime} \geq 0, \mathrm{~B}_{\mathrm{i}}^{\prime \prime}<0$. In the absence of climate policies, countries would emit up to their so-called business-as-usual emission level $\mathrm{e}_{\mathrm{i}}^{\mathrm{BAU}}$ which is defined as the level of emissions satisfying $\mathrm{B}_{\mathrm{i}}^{\prime}\left(\mathrm{e}_{\mathrm{i}}^{\mathrm{BAU}}\right)=0$, i.e. the welfare maximizing emissions level if permits and carbon emissions were free. To evaluate the impact of bilateral contracts we first describe the outcome of the permit trading in the absence of such contracts.

\section{Permit trade in the absence of bilateral contracts}

\subsection{Competitive market participants}

We assume that there is a nonempty subset of agreement members that behave as price takers in the permit market. This subset of countries will be called the competitive fringe and is denoted by $\mathrm{F} \subseteq \mathrm{K}$. Every fringe member takes the price of permits as given and chooses its emissions level in order to maximize individual net benefits:

$$
\max _{\mathrm{e}_{\mathrm{f}}} \mathrm{W}_{\mathrm{f}}=\mathrm{B}_{\mathrm{f}}\left(\mathrm{e}_{\mathrm{f}}\right)+\mathrm{p} \cdot\left[\varepsilon_{\mathrm{f}}-\mathrm{e}_{\mathrm{f}}\right] \quad \forall \mathrm{f} \in \mathrm{F}
$$

The solution of this maximization exercise gives rise to the standard first-order conditions:

$$
\mathrm{B}_{\mathrm{f}}^{\prime}\left(\mathrm{e}_{\mathrm{f}}\right)=\mathrm{p} \quad \forall \mathrm{f} \in \mathrm{F}
$$

For every price-taking member of the fringe, the first-order condition (5) defines an implicit emissions function:

$$
\mathrm{e}_{\mathrm{f}}=\mathrm{B}_{\mathrm{f}}^{\prime-1}(\mathrm{p}), \quad \frac{\mathrm{de}_{\mathrm{f}}}{\mathrm{dp}}=\frac{1}{\mathrm{~B}_{\mathrm{f}}^{\prime \prime}}<0, \quad \forall \mathrm{f} \in \mathrm{F},
$$

where $\mathrm{de}_{\mathrm{f}} / \mathrm{dp}$ is found from totally differentiating the first order condition (5). Aggregating these implicit emissions functions over all fringe members and inverting, yields a downward 
sloping, inverse aggregate emissions permit demand function for the group of fringe countries:

$$
p=p\left(e_{F}\right), \quad p^{\prime}=\frac{1}{\sum_{f \in F} \frac{1}{B^{\prime \prime}}{ }_{f}}<0
$$

\subsection{Noncompetitive market participants}

For large players in the permit market, the assumption of price-taking behavior is hard to maintain and we therefore believe it is crucial to relax this assumption for an adequate representation of reality. The group of strategic permit traders is denoted by $\mathrm{S} \subseteq \mathrm{K}$ and together with the fringe, these two subsets are forming a partition of the set of post-Kyoto climate agreement members: $\mathrm{F} \cup \mathrm{S}=\mathrm{K}$ and $\mathrm{F} \cap \mathrm{S}=\varnothing$. The total emission constraint (2), can now be rewritten as:

$$
\sum_{\mathrm{f} \in \mathrm{F}} \mathrm{e}_{\mathrm{f}}+\sum_{\mathrm{s} \in \mathrm{S}} \mathrm{e}_{\mathrm{s}} \equiv \mathrm{e}_{\mathrm{F}}+\mathrm{e}_{\mathrm{S}}=\varepsilon_{\mathrm{K}}
$$

We assume that the strategic choice variable of the noncompetitive agents are emissions quantities. In this section we are assuming that strategic permit traders behave as individual Cournot players if there is more than one large noncompetitive permit trader. In section 4.4 we will relax this Cournot competition assumption and we will discuss the consequences for the permit market outcome if the noncompetitive strategic players collude to establish cartels.

The maximization problem of an individual strategic permit trader $\mathrm{s}$ is given by:

$$
\max _{\mathrm{e}_{\mathrm{s}}} \quad \mathrm{W}_{\mathrm{s}}=\mathrm{B}_{\mathrm{s}}\left(\mathrm{e}_{\mathrm{s}}\right)+\mathrm{p}\left(\mathrm{e}_{\mathrm{F}}\right) \cdot\left[\varepsilon_{\mathrm{s}}-\mathrm{e}_{\mathrm{s}}\right] \quad \forall \mathrm{s} \in \mathrm{S}
$$

subject to (7) and (8). The first-order condition for this maximization problem is given by:

$$
\mathrm{B}_{\mathrm{s}}^{\prime}=\mathrm{p}+\mathrm{p}^{\prime} \cdot\left[\varepsilon_{\mathrm{s}}-\mathrm{e}_{\mathrm{s}}\right] \quad \forall \mathrm{s} \in \mathrm{S}
$$

And the corresponding second-order condition for a maximum is:

$$
\mathrm{B}_{\mathrm{s}}^{\prime \prime}+2 \cdot \mathrm{p}^{\prime}+\mathrm{p}^{\prime \prime} \cdot\left[\varepsilon_{\mathrm{s}}-\mathrm{e}_{\mathrm{s}}\right]<0 \quad \forall \mathrm{s} \in \mathrm{S}
$$


We assume in the following that the second-order condition is always satisfied. ${ }^{8}$ Furthermore, to ensure the existence of a unique stable equilibrium, we assume throughout the paper, that the aggregate reaction function is downward sloping with an absolute value less than unity ${ }^{9}$. The first-order condition in (10), shows the standard result that dominant sellers supply too few permits (hence emit too much) in order to drive up the market price compared to the competitive market outcome. Dominant sellers' marginal benefits of emissions are therefore lower than marginal benefit of emissions in the fringe, and emissions are not cost-effectively distributed across countries ${ }^{10}$ :

$$
\mathrm{B}_{\mathrm{s}}^{\prime}<\mathrm{B}_{\mathrm{f}}^{\prime}=\mathrm{p} \quad \forall \mathrm{s} \in \mathrm{S} \text { for which } \varepsilon_{\mathrm{s}}>\mathrm{e}_{\mathrm{s}}
$$

\section{Bilateral permit trade contracts offered by the EU}

\subsection{Nature of bilateral permit trade contracts}

We consider a situation in which the EU takes an initiative to offer permit trade contracts to one or several other market participants prior to the beginning of the trading period. All of the participating countries know their permit allowances for the post-Kyoto period at the time the contracts are offered. Throughout the paper we assume that the EU cannot force its member states to act strategically on the permit market when purchasing permits. However, the EU Commission can act on behalf of its member states and can offer other countries permit trade contracts. These contracts involve a minimum permit sales requirement, complemented by a financial transfer from the EU to the other contract party. The benefits of the contracts depend on the subsequent outcome of the international permit market. To model this situation consistently we consider a two-stage game. In the first stage, the EU designs contracts to be offered to one or several of the strategic players on a take-it-or-leave-it basis. In the second stage emission permits are traded and the equilibrium price, transaction volumes and payoffs are determined. This sequential game will be solved by backward induction. Section 4.2 deals

\footnotetext{
${ }^{8}$ Note that the second-order condition depends on second derivative of the equilibrium price function, hence on third derivative properties of the emissions benefit function. Assuming that the second-order condition is always satisfies means basically that that the magnitude of the second derivative of the price function should not be too large.

${ }^{9}$ That is (in general), $-1<\partial \sum_{\mathrm{j} \in \mathrm{S}, \mathrm{j} \neq \mathrm{s}} \mathrm{e}_{\mathrm{j}} / \partial \mathrm{e}_{\mathrm{s}}<0 \quad \forall \mathrm{s} \in \mathrm{S}$.

${ }^{10}$ A similar, but reverse, argument applies to dominant permit buyers who have an interest in limiting their demand for permits in order to drive down the market price.
} 
with the second stage of the game, i.e. the permit trading phase. In Section 4.3 we address the first stage of the game, i.e. the design of the optimal contracts. The choice of contract partners is addressed in Section 4.4.

We refer to the countries being offered a contract by the EU as contract partners. Hence, we split the group of strategic players $\mathrm{S}$ is in two subgroups, the contract partners $\mathrm{CP}$ and the rest of the strategic players RS. Note that as the EU chooses which countries to offer the contracts, the segregation of strategic players S into the two groups is determined by the EU. To explore these contracts it is also necessary to split up the set $\mathrm{F}$ of fringe countries into two parts: EU members and non EU members. In terms of emissions this implies:

$$
\begin{aligned}
& \mathrm{e}_{\mathrm{S}}=\mathrm{e}_{\mathrm{CP}}+\mathrm{e}_{\mathrm{RS}}, \\
& \mathrm{e}_{\mathrm{CP}}=\sum_{\mathrm{c} \in \mathrm{CP}} \mathrm{e}_{\mathrm{c}} \text { and } \mathrm{e}_{\mathrm{RS}}=\sum_{\mathrm{r} \in \mathrm{RS}} \mathrm{e}_{\mathrm{r}} . \\
& \mathrm{e}_{\mathrm{F}}=\mathrm{e}_{\mathrm{EU}}+\mathrm{e}_{\mathrm{RF}} \\
& \mathrm{e}_{\mathrm{EU}}=\sum_{\mathrm{i} \in \mathrm{EU}} \mathrm{e}_{\mathrm{i}} \text { and } \mathrm{e}_{\mathrm{RF}}=\sum_{\mathrm{j} \in \mathrm{RF}} \mathrm{e}_{\mathrm{j}} .
\end{aligned}
$$

where subscript EU refers to the EU countries taken together and subscript RF refers to the rest of the fringe countries. In terms of permit allocation, it should hold that:

$$
\begin{aligned}
& \varepsilon_{\mathrm{S}}=\varepsilon_{\mathrm{CP}}+\varepsilon_{\mathrm{RS}}=\sum_{\mathrm{c} \in \mathrm{CP}} \varepsilon_{\mathrm{c}}+\sum_{\mathrm{r} \in \mathrm{RS}} \varepsilon_{\mathrm{r}} \\
& \varepsilon_{\mathrm{F}}=\varepsilon_{\mathrm{EU}}+\varepsilon_{\mathrm{RF}}=\sum_{\mathrm{i} \in \mathrm{EU}} \varepsilon_{\mathrm{i}}+\sum_{\mathrm{j} \in \mathrm{RF}} \varepsilon_{\mathrm{j}}
\end{aligned}
$$

The EU offers each contract partner c a contract that specifies a fixed transfer $T_{c}$ plus a minimum emissions permit sales constraint $\overline{\mathrm{e}}_{\mathrm{c}}$. This corresponds to a contract which specifies a fixed monetary transfer and a maximum amount of emissions (or equivalently a minimum amount of emission abatement) by the contract partner in the second stage. We assume that the contracts are offered simultaneously to all of the contract partners as a take-it-or-leave-it offer, and no contract is signed if not all of the contract partners accept their contract. Each contract partner faces the following emission constraint in stage two:

$$
\mathrm{e}_{\mathrm{c}} \leq \overline{\mathrm{e}}_{\mathrm{c}} \quad \forall \mathrm{c} \in \mathrm{CP}
$$


where $\overline{\mathrm{e}}_{\mathrm{c}}$ denotes the maximum emission level by the contract partner specified in the contract. We assume in the following that the emission constraint is binding such that emissions from each contract partner in stage two equals $\overline{\mathrm{e}}_{\mathrm{c}}{ }^{11}$.

In order for the contract partner to accept the contract, it must be at least as well off with the contract as without. The contract partners' participation constraints are given by:

$$
\mathrm{W}_{\mathrm{c}}\left(\overline{\mathrm{e}}_{\mathrm{c}}, \mathrm{T}_{\mathrm{c}}\right)=\mathrm{B}_{\mathrm{c}}\left(\overline{\mathrm{e}}_{\mathrm{c}}\right)+\tilde{\mathrm{p}} \cdot\left[\varepsilon_{\mathrm{c}}-\overline{\mathrm{e}}_{\mathrm{c}}\right]+\mathrm{T}_{\mathrm{c}} \geq \mathrm{W}_{\mathrm{c}}^{*} \quad \forall \mathrm{c} \in \mathrm{CP}
$$

where $\tilde{\mathrm{p}}$ denotes the equilibrium permit price in the second stage given bilateral permit contracts and $\mathrm{W}_{\mathrm{c}}^{*}$ is the contract partners' welfare if the contract offer is turned down (i.e. its outside option). If the contract is turned down, and none of the strategic players coordinate their permit trade in the second period, $\mathrm{W}_{\mathrm{c}}^{*}$ correspond to the outcome of the permit trade derived in Section 3.2, the noncompetitive permit market outcome. Since financial transfers are costly for the EU, it will ensure that participation constraints (18) are satisfied with equality. The financial transfer which ensures that (18) is satisfied with equality is denoted by $\widetilde{T}_{c}$ and is a function of the outcome of the permit price in the second period, $\tilde{p}$, the emission restriction specified in the contract, $\overline{\mathrm{e}}_{\mathrm{c}}$, and the outside option, $\mathrm{W}_{\mathrm{c}}^{*}$ :

$$
\widetilde{\mathrm{T}}_{\mathrm{c}}=\mathrm{W}_{\mathrm{c}}^{*}-\mathrm{B}_{\mathrm{c}}\left(\overline{\mathrm{e}}_{\mathrm{c}}\right)-\tilde{\mathrm{p}} \cdot\left[\varepsilon_{\mathrm{c}}-\overline{\mathrm{e}}_{\mathrm{c}}\right] \quad \forall \mathrm{c} \in \mathrm{CP}
$$

When the financial compensation in the permit sales contract is given by (19), the contract partner has no incentive to breach the contract.

\subsection{Stage 2: permit trading}

The EU's permit trade contracts in stage one do not affect first-order conditions, given by (5), for the group of agents within the competitive fringe, nor the inverse demand function, given by (7). The bilateral contracts of stage one turn the contract partners into Stackelberg leaders in the permit market in the second stage, as they have made a binding contract with the EU to limit their permit sale. The other strategic agents therefore take the output from the contracts partners as given when they optimize their emission/permit sale in stage two. Hence, the other large strategic traders' optimizing problem in stage two is given by:

\footnotetext{
${ }^{11} \mathrm{e}_{\mathrm{c}}$ is given by (10) if the contract partner's emission constraint would not be binding.
} 


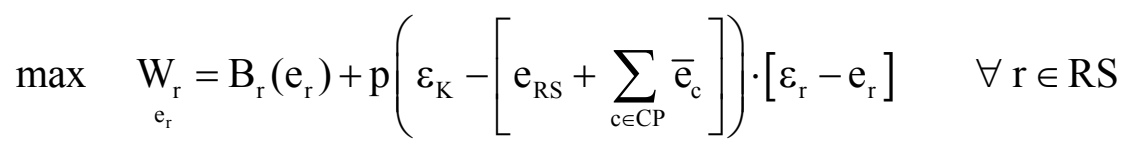

and the corresponding first-order condition is given by:

$$
\mathrm{B}_{\mathrm{r}}^{\prime}=\mathrm{p}\left(\varepsilon_{\mathrm{K}}-\left[\mathrm{e}_{\mathrm{RS}}+\sum_{\mathrm{c} \in \mathrm{CP}} \overline{\mathrm{e}}_{\mathrm{c}}\right]\right)+\mathrm{p}^{\prime} \cdot\left[\varepsilon_{\mathrm{r}}-\mathrm{e}_{\mathrm{r}}\right] \quad \forall \mathrm{r} \in \mathrm{RS}
$$

leading to the optimal emission levels $\tilde{\mathrm{e}}_{\mathrm{r}}\left(\sum_{\mathrm{c} \in \mathrm{CP}} \overline{\mathrm{e}}_{\mathrm{c}}\right)$ for all $\mathrm{r} \in \mathrm{RS}$. The second-order conditions $\mathrm{B}^{\prime \prime}\left(\mathrm{e}_{\mathrm{r}}\right)+2 \mathrm{p}^{\prime}+\mathrm{p}^{\prime \prime} \cdot\left(\varepsilon_{\mathrm{r}}-\mathrm{e}_{\mathrm{r}}\right)<0$ are assumed to be always satisfied. From (7), (8), (13) and (21), we can write the equilibrium permit price and emissions from the EU, and RS, denoted $\tilde{p}, \tilde{e}_{\mathrm{EU}}$ and $\tilde{\mathrm{e}}_{\mathrm{RS}}$ respectively, as functions of the sum of emissions from the contract partners; $\tilde{\mathrm{p}}=\tilde{\mathrm{p}}\left(\sum_{\mathrm{c} \in \mathrm{CP}} \overline{\mathrm{e}}_{\mathrm{c}}\right), \tilde{\mathrm{e}}_{\mathrm{EU}}=\tilde{\mathrm{e}}_{\mathrm{EU}}\left(\sum_{\mathrm{c} \in \mathrm{CP}} \overline{\mathrm{e}}_{\mathrm{c}}\right)$ and $\tilde{\mathrm{e}}_{\mathrm{RS}}=\tilde{\mathrm{e}}_{\mathrm{RS}}\left(\sum_{\mathrm{c} \in \mathrm{CP}} \overline{\mathrm{e}}_{\mathrm{c}}\right)^{12}$. Furthermore, as $\tilde{\mathrm{p}}=\tilde{\mathrm{p}}\left(\sum_{\mathrm{c} \in \mathrm{CP}} \overline{\mathrm{e}}_{\mathrm{c}}\right)$, we see from (19) that $\widetilde{\mathrm{T}}_{\mathrm{c}}$ can be written as a function of $\sum_{\mathrm{c} \in \mathrm{CP}} \overline{\mathrm{e}}_{\mathrm{c}}$ and $\mathrm{W}_{\mathrm{c}}^{*} ; \widetilde{\mathrm{T}}_{\mathrm{c}}=\widetilde{\mathrm{T}}_{\mathrm{c}}\left(\sum_{\mathrm{c} \in \mathrm{CP}} \overline{\mathrm{e}}_{\mathrm{c}}, \mathrm{W}_{\mathrm{c}}^{*}\right)$.

We can now turn to analyzing optimal design of the contracts offered in the first stage of the game.

\subsection{Stage 1: optimal contract design}

In the first stage the EU chooses which countries to offer a contract and the design of the contracts offered. In a first step we derive the optimal design of the contracts to be offered to a particular combination of contract partners. In the second step (see Section 4.4) we derive the optimal combinations of contract partners. For a particular combination of contract partners $\mathrm{CP}$, the EU optimizes the contract variables, i.e. the minimal permit sales or maximum emission levels $\overline{\mathrm{e}}_{\mathrm{q}} \quad \forall \mathrm{q} \in \mathrm{CP}$ it demands from each of its contract partners, as to maximize the following objective:

\footnotetext{
$12 \tilde{\mathrm{p}}=\tilde{\mathrm{p}}\left(\sum_{\mathrm{c} \in \mathrm{CP}} \overline{\mathrm{e}}_{\mathrm{c}}\right)=\mathrm{p}\left(\varepsilon_{\mathrm{K}}-\left[\tilde{\mathrm{e}}_{\mathrm{RS}}\left(\sum_{\mathrm{c} \in \mathrm{CP}} \overline{\mathrm{e}}_{\mathrm{c}}\right)+\sum_{\mathrm{c} \in \mathrm{CP}} \overline{\mathrm{e}}_{\mathrm{c}}\right]\right), \tilde{\mathrm{e}}_{\mathrm{RS}}\left(\sum_{\mathrm{c} \in \mathrm{CP}} \overline{\mathrm{e}}_{\mathrm{c}}\right)=\sum_{\mathrm{s} \in \mathrm{RS}} \tilde{\mathrm{e}}_{\mathrm{s}}\left(\sum_{\mathrm{c} \in C \mathrm{CP}} \overline{\mathrm{e}}_{\mathrm{c}}\right)$ and $\tilde{\mathrm{e}}_{\mathrm{EU}}\left(\sum_{\mathrm{c} \in \mathrm{CP}} \overline{\mathrm{e}}_{\mathrm{c}}\right)=\sum_{\mathrm{i} \in \mathrm{EU}} \tilde{\mathrm{e}}_{\mathrm{i}}\left(\sum_{\mathrm{c} \in \mathrm{CP}} \overline{\mathrm{e}}_{\mathrm{c}}\right)$ where $\tilde{\mathrm{e}}_{\mathrm{i}}\left(\sum_{\mathrm{i} \in \mathrm{EU}} \overline{\mathrm{e}}_{\mathrm{c}}\right)$ is found from (5) for $\mathrm{p}=\tilde{\mathrm{p}}$.
} 


$$
\max _{\left\{\overline{\mathrm{e}}_{\mathrm{q}}\right\}_{\mathrm{q} \in \mathrm{CP}}} \mathrm{W}_{\mathrm{EU}}=\mathrm{B}_{\mathrm{EU}}\left(\tilde{\mathrm{e}}_{\mathrm{EU}}\right)+\tilde{\mathrm{p}} \cdot\left[\varepsilon_{\mathrm{EU}}-\tilde{\mathrm{e}}_{\mathrm{EU}}\right]-\sum_{\mathrm{c} \in \mathrm{CP}} \widetilde{\mathrm{T}}_{\mathrm{c}}
$$

where $B_{\mathrm{EU}}\left(\tilde{\mathrm{e}}_{\mathrm{EU}}\right)$ denotes the EU's joint benefit of the sum of emission from all the EUcountries. Emissions from all EU countries follow from price taking behaviour of each member state as reflected by first-order conditions (5). ${ }^{13}$ Inserting from these first-order condition for the EU countries, we can write the first-order condition of EU's optimization problem for the contract variables as ${ }^{14}$ :

$$
-\tilde{\mathrm{p}}^{\prime} \cdot\left[\varepsilon_{\mathrm{EU}}-\tilde{\mathrm{e}}_{\mathrm{EU}}\right]=-\sum_{\mathrm{c} \in \mathrm{CP}} \frac{\partial \widetilde{\mathrm{T}}_{\mathrm{c}}}{\partial \overline{\mathrm{e}}_{\mathrm{q}}} \quad \forall \mathrm{q} \in \mathrm{CP}
$$

The right hand side of (23) equals the regulator's change in transfer costs of demanding one unit more of permit sales from contract partner q. The left hand side of (23) equals the regulator's marginal benefit of the resulting change in equilibrium permit price. The optimal $\overline{\mathrm{e}}_{\mathrm{q}}$ for contract partner $\mathrm{q}$ is the solution to the first-order condition (23) equating the marginal benefit and costs of the last unit of $\overline{\mathrm{e}}_{\mathrm{q}}$. Obviously, the EU's welfare is depending on the choice of contract partners. Let $\mathrm{W}_{\mathrm{EU}}^{*}(\mathrm{CP})$ denote the EU's welfare given optimal contracts for a particular combination of contract partners CP. We find $\partial \tilde{\mathrm{T}}_{\mathrm{c}} / \partial \overline{\mathrm{e}}_{\mathrm{q}}$ from total differentiation of (19):

$$
\begin{array}{ll}
\frac{\partial \tilde{\mathrm{T}}_{\mathrm{c}}}{\partial \overline{\mathrm{e}}_{\mathrm{q}}}=\tilde{\mathrm{p}}-\mathrm{B}_{\mathrm{c}}^{\prime}-\frac{\partial \tilde{\mathrm{p}}}{\partial \overline{\mathrm{e}}_{\mathrm{q}}} \cdot\left[\varepsilon_{\mathrm{c}}-\overline{\mathrm{e}}_{\mathrm{c}}\right] & \text { for } \quad \mathrm{q} \in \mathrm{CP}, \mathrm{c} \in \mathrm{CP}, \mathrm{q}=\mathrm{c} \\
\frac{\partial \tilde{\mathrm{T}}_{\mathrm{c}}}{\partial \overline{\mathrm{e}}_{\mathrm{q}}}=-\frac{\partial \tilde{\mathrm{p}}}{\partial \overline{\mathrm{e}}_{\mathrm{q}}} \cdot\left[\varepsilon_{\mathrm{c}}-\overline{\mathrm{e}}_{\mathrm{c}}\right] \quad \text { for } \quad \mathrm{q} \in \mathrm{CP}, \mathrm{c} \in \mathrm{CP}, \mathrm{q} \neq \mathrm{c}
\end{array}
$$

Hence, (23) can be written as:

$$
-\tilde{\mathrm{p}}^{\prime} \cdot\left[\sum_{\mathrm{c} \in \mathrm{CP}} \varepsilon_{\mathrm{c}}+\varepsilon_{\mathrm{EU}}-\left[\mathrm{e}_{\mathrm{EU}}+\sum_{\mathrm{c} \in \mathrm{CP}} \overline{\mathrm{e}}_{\mathrm{c}}\right]\right]=\tilde{\mathrm{p}}-\mathrm{B}_{\mathrm{c}}^{\prime} \quad \forall \mathrm{c} \in \mathrm{CP} .
$$

From (25), we derive the following propositions:

\footnotetext{
${ }^{13}$ Given that (5) is satisfied for all EU counties $B_{\mathrm{EU}}^{\prime}=\mathrm{B}_{\mathrm{i}}^{\prime}=\tilde{\mathrm{p}}$ for all $\mathrm{i} \in \mathrm{EU}$,

${ }^{14}$ Subscript $\mathrm{c}$ and $\mathrm{q}$ both denote contract partners.
} 


\section{Proposition 1}

The EUs optimal design of the permit trade contract offered to each of its contract partners is characterized by $\tilde{\mathrm{p}}=\mathrm{B}_{\mathrm{EU}}^{\prime}<\mathrm{B}_{\mathrm{c}}^{\prime}$ if the EU and the contract partner jointly become net buyers of permits, and is characterized by $\tilde{\mathrm{p}}=\mathrm{B}_{\mathrm{EU}}^{\prime}>\mathrm{B}_{\mathrm{c}}^{\prime}$ if they jointly become net sellers of permits.

Proof of Proposition 1: See appendix.

\section{Proposition 2}

If the EU offers permit trade contracts to more than one contract partner, the contracts implies equal marginal abatement costs across its trading partners.

Proof of Proposition 2: See appendix.

\section{Proposition 3}

The optimal design of the permit trade contract between the EU and its partner(s) lead to higher supply of permits from its partner(s) and a lower equilibrium permit price, than without contracts under the following conditions;

a) The EU has only one contract partner.

b)The EU and its contract partners become net buyers of permits.

If the EU has more than one contract partner and EU and its contract partners become net sellers of permit, the optimal design of the permit trade contracts may lead to lower supply of permits from its partners and a higher equilibrium permit price, than without contracts.

Proof of Proposition 3: See appendix.

The EU cannot force its member states to act strategically on the permit market when purchasing permits in the second stage. However, the EU may act strategically through negotiations with other countries in the first stage. Demanding a larger quantity of permit sales from its contract partners than what is optimal for them (in the absence of bilateral contracts), drives the permit price down, which benefits the permit importing EU member states. However, driving down the permit price has a cost as the contract partners have to be 
compensated financially for observing the contract's restrictions. Furthermore, larger permit sales from one contract partner also affects the transfers to the other contract partners, as they will also be affected by the corresponding change in the equilibrium permit price (see right hand side of (23). The EU faces a trade off between on the one hand inducing contract partners to increase their supply of permits, leading to a lower equilibrium permit price, and on the other and paying higher financial transfers in order to satisfy the contract partners' participation constraints.

As long as net demand for permits from the EU countries is higher than the supply of permits from its contract partners, it is optimal for the EU to manipulate the permit price downward by stimulating permit sales from its contract partners. Hence, the EU acts as a strategic buyer of permits in that case. On the other hand, if net permit purchase from the EU is lower than the permit sale from its contract partner, the EU act as a strategic seller of permits. The EU determines the permit sale from its contract partners such that marginal benefits from emission in the countries of the contract partners are lower than the permit price.

One can not rule out a priori the possibility that for some combination of contract partners, the EU manipulates the permit price above the level of the equilibrium permit price in case of no contracts. However, such a policy implies that the financial transfer $\sum_{c \in C P} \widetilde{T}_{c}$ must be negative to ensure EU a non-negative profit of offering the contracts. In that case the EU acts as a "cartel organizer" and is paid for that by the contract partners. Admittedly, such a situation is highly unrealistic since it is politically unthinkable that countries like Russia or China would observe tighter emission ceilings and in addition pay a financial transfer to the EU. Therefore, we will ignore these cases if they would occur in the numerical simulations.

If the combination of contract partners implies that the EU and its contract partners become net buyers of permits or the EU has only one contract partner, the EU may manipulate the permit price such that the equilibrium price becomes higher than in case of a competitive supply of permits from its contract partners (characterized by $\mathrm{p}=\mathrm{B}_{\mathrm{c}}^{\prime}$ ), but the contract(s) will lead to an increase in permit sale and a fall in the permit price compared to no contract. (see proposition 3). There are two reasons for this. First, the bilateral contract makes the contract partners Stackelberg leaders in the permit market. This effect ceteris paribus increases the total supply of permits. Second, for any given amount of permit sales from the contract partners, the net supply of permits from EU and its contract partners is jointly lower, as the 
EU countries are net buyers. This increases the marginal revenue of permit sales and leads to a larger equilibrium permit sale from the contract partners.

Since the regulator cannot determine the permit trade from the EU countries directly, marginal benefits of emissions differ between the contract partners and the EU countries. This implies that the emission reductions in the contract partners/EU coalition are not distributed in a cost-effective way. Hence, there would be room for further cost reductions if the EU also could determine the emission reductions among EU countries. However, that is assumed not to be an option for the EU regulator. We do observe however that the EU designs the contracts such the marginal cost of an additional permit sale is identical across all contract partners. We see from (23) that marginal transfer costs are equalized across trading partners.

\subsection{Stage 1: choosing contract partners}

In the previous section we derived the optimal design of the permit trade contracts for a particular set of contract partners. In this section we discuss the optimal combinations of contract partners. The preferred combination of contract partners can be found by comparing the EU's payoff under the optimal contracts for each combination of potential trading partners. Since there are s strategic trading partner, that means that $2^{\mathrm{s}}-1$ subsets of trading partners are to be considered. The EU optimization problem is to choose the optimal coalition of contract partner, $\mathrm{CP}$, among the strategic agents $\mathrm{S}$, which maximizes EU's welfare:

$$
\underset{\mathrm{CP}}{\operatorname{Max}}\left\{\mathrm{W}_{\mathrm{EU}}^{*}(\mathrm{CP}) \mid \mathrm{CP} \subset \mathrm{S}\right\}
$$

where $\mathrm{W}_{\mathrm{EU}}^{*}(\mathrm{CP})$ is the EU's maximal payoff under the optimal contract for $\mathrm{CP}$, i.e. the solution to (23) for all $\mathrm{c} \in \mathrm{CP}$.

As can bee seen from (19), the financial transfer is increasing in the contract partner's outside option. Hence, the potential contract partners' outside option is crucial for the EUs gain from the contract and the optimal choice of contract partners. In the previous section we assumed that all strategic agents behave as individually Cournot players in the permit market. In that case, the outside option $\mathrm{W}_{\mathrm{c}}^{*}$ is the welfare the potential contract partner would achieve as an individual Cournot player. One the other hand, if we consider the possibility that the strategic agents may collude in the permit market, the outside option corresponds to the outcome of a cartel market. In the numerical illustration in the next section, we derive the optimal 
contract(s) for the EU given that the strategic players which are not contracts partner may establish sales cartels with other strategic agents. When we consider the various possibilities for outside options, we do only consider stable cartels among the strategic agents. For cartel stability we use the stability concept introduced by d'Aspremont et al. (1983). A cartel is said to be stable if it is both internally stable, i.e. no member wants to leave the cartel, and externally stable, i.e. no non-member wants to join the cartel.

\section{Numerical illustration}

In November-December 2007, the international negotiators at the $13^{\text {th }}$ Conference of the Parties $(\mathrm{CoP})$ of the UNFCCC in Bali have agreed upon a roadmap for negotiations that should lead to a new climate agreement for the post-Kyoto period, i.e. 2013 and beyond. However, no consensus has been reached yet on the group of signatories, the global future emission target, let alone the regional burden sharing. Therefore, in the numerical illustration we are forced to make assumptions on the provisions of a possible follow-up climate agreement. In particular, we assume that the same group of countries that accepted binding emissions ceilings in the Kyoto Protocol will continue to do so in the post-Kyoto period and we focus on possible expansions of this group. In particular we assume that the USA joins a Kyoto follow-up agreement. Because of the relatively poor global emission reduction achieved by the 1997 Kyoto Protocol for the first commitment period, we find it reasonable to assume that a future climate agreement will specify more stringent emission targets for its ratifiers. In particular, we assume an emission target for the ratifying countries that is $20 \%$ below 1990 emissions levels ${ }^{15}$. For the USA however, we assume in accordance with recent political developments (Waxman-Markey bill) a 4\% reduction compared to 1990 emission levels.

There is a large literature on International Environmental Agreements (IEA) and the stability of such agreements see, e.g. Barrett (1999) and Chander and Tulkens (1995) or Finus (2003). Stability of a future IEA is however not the prime focus of this paper, see Bréchet et al. (2009) for a stability analysis of future climate agreements. We assume that signatories to the 1997 Kyoto Protocol also participate in the post-Kyoto agreement, including the USA, Australia and Canada. In addition, we believe that also a Kyoto follow-up agreement will

\footnotetext{
${ }^{15}$ Minus $20 \%$ is in line with the proposal made by the EU after the 2007 Spring meeting of Ministers of Environment, for a new international climate agreement for the post-Kyoto period.
} 
contain provisions for flexibility mechanisms like a cap-and-trade system. Concerning market power in the resulting international permit market, we assume that in the post-Kyoto period, there is at least one (group of) large permit seller(s) that behaves strategically, i.e. that withholds some supply out of the market in order to drive up the permit price and their permit trading profits.

Furthermore, we assume that developing countries are invited to join the treaty ${ }^{16}$. If they join, they receive an allocation of permits corresponding to their business-as-usual emissions and are allowed to trade on the permit market on equal terms as the developed countries. This assumption ensures that participation cannot decrease the developing countries' (expected) welfare, compared to not participating. ${ }^{17}$ An alternative interpretation of our numerical model is that developing countries do not formally participate in the post-Kyoto agreement, but contribute to emissions reductions through a kind of project based emission trade scheme like the current CDM-mechanism. Ignoring any transaction cost and problems with real emissions reduction measures, and assuming that all emissions reductions possibilities are eligible for CDM-projects, the CDM-mechanism corresponds to a situation where developing countries are assigned permits equal to their BaU-emissions and participate in emission trading. ${ }^{18}$

\subsection{Description simulation model}

We now describe the numerical simulation exercise illustrating and complementing the theoretical results that were derived in the previous sections. The exercise is based on a stylized numerical simulation model of the major players in the Kyoto carbon emission permit market. Each participant in the Kyoto carbon permit market is characterized by a marginal carbon emission benefit function with the following functional form:

$$
B_{i}^{\prime}\left(e_{i}\right)=\gamma_{i} \ln \left(\frac{e_{i}}{e_{i}^{B A U}}\right) \quad \text { with } \gamma_{i}<0
$$

The benefit function is concave in emissions since $B_{i}^{\prime \prime}\left(e_{i}\right)=\gamma_{i} / e_{i}<0$. Note that marginal benefits are zero when emissions equal their BAU level $\left(\mathrm{B}_{i}^{\prime}\left(\mathrm{e}_{i}^{\mathrm{BAU}}\right)=0\right)$. Hence, BAU

\footnotetext{
${ }^{16}$ The EUs benefit of a developing country's participation in the climate agreement due to the subsequent fall in the permit price is analyzed in Buchner and Carraro (2003). However, they do not consider any strategic behaviour on the permit market.

${ }^{17}$ Developing countries have been very reluctant to accept any kind of binding target for their emissions, although they clearly benefit from participating in permit trading if their initial allocation of permits is generous. ${ }^{18}$ Due to possible high transaction costs, and problems connected with estimating real emission reduction, the CDM mechanism has met much criticism, See, among others, Bohm (2002), Fischer (2005) and Repetto (2001).
} 
emissions maximize benefits in the absence of carbon pricing. Marginal benefits tend to infinity when emissions are approaching zero $\left(\lim _{e_{i} \rightarrow 0} B_{i}^{\prime}\left(e_{i}\right)=+\infty\right)$. The marginal benefit of emission functions can be reinterpreted as the marginal cost of cutting back emissions by one more percent by defining a new variable $r_{i} \equiv 1-e_{i} / e_{i}^{B A U}$ as the emission reduction relative to business-as-usual (BAU) emissions:

$$
\mathrm{C}_{\mathrm{i}}^{\prime}\left(\mathrm{r}_{\mathrm{i}}\right) \equiv \gamma_{\mathrm{i}} \ln \left(1-\mathrm{r}_{\mathrm{i}}\right)=\gamma_{\mathrm{i}} \ln \left(\frac{\mathrm{e}_{\mathrm{i}}}{\mathrm{e}_{\mathrm{i}}^{\mathrm{BAU}}}\right)=\mathrm{B}_{\mathrm{i}}^{\prime}\left(\mathrm{e}_{\mathrm{i}}\right)
$$

Hence, marginal benefit of emissions functions are the mirror images of marginal cost of abatement functions. This is important for our purposes because it implies that we can easily calibrate the parameters $\gamma_{i}$ of the marginal benefit functions from estimates of marginal emission reduction costs derived from, for instance, simulations with large scale general equilibrium models.

For the price-taking players of the competitive fringe, the first-order condition for an interior solution to the benefit maximization exercise can be used to derive the following relationship between individual emission levels and permit price:

$$
p=\gamma_{f} \cdot \ln \left(\frac{e_{f}}{e_{f}^{B A U}}\right) \quad \Rightarrow \quad e_{f}=e_{f}^{B A U} \cdot \exp \left(\frac{p}{\gamma_{f}}\right) \quad \forall f \in F
$$

Summing the latter expression over all fringe members we can derive the aggregate demand for carbon emissions function of the price-taking fringe countries:

$$
\mathrm{e}_{\mathrm{F}} \equiv \sum_{\mathrm{f} \in \mathrm{F}} \mathrm{e}_{\mathrm{f}}=\sum_{\mathrm{f} \in \mathrm{F}} \mathrm{e}_{\mathrm{f}}^{\mathrm{BAU}} \cdot \exp \left(\frac{\mathrm{p}}{\gamma_{\mathrm{f}}}\right)
$$

For $\mathrm{p}=0$, no emission reduction is performed and actual emissions coincide with BAU emissions. If the price of emission permits tends towards infinity, emissions tend to zero. From the aggregate demand function for emissions of all fringe countries, we can easily establish that their emissions depend negatively on the price of permits since:

$$
\mathrm{p}^{\prime}=\frac{\mathrm{dp}}{\mathrm{de}_{\mathrm{F}}}=\left[\sum_{\mathrm{f} \in \mathrm{F}} \frac{\mathrm{e}_{\mathrm{f}}^{\mathrm{BAU}}}{\gamma_{\mathrm{f}}} \cdot \exp \left(\frac{\mathrm{p}}{\gamma_{\mathrm{f}}}\right)\right]^{-1}<0
$$


For the noncompetitive players in the model, we can write the following first-order conditions for an interior solution to their benefit maximization exercise ${ }^{19}$ :

$$
\begin{array}{ll}
\mathrm{B}_{j}^{\prime}\left(\frac{\mathrm{e}_{\mathrm{j}}}{\mathrm{e}_{\mathrm{j}}^{\mathrm{BAU}}}\right)=\mathrm{p}+\mathrm{p}^{\prime} \cdot\left[\varepsilon_{\mathrm{C}}-\mathrm{e}_{\mathrm{C}}\right] \quad & \forall \mathrm{j} \in \mathrm{C} \subseteq \mathrm{S} \\
\mathrm{B}_{\mathrm{i}}^{\prime}\left(\frac{\mathrm{e}_{\mathrm{i}}}{\mathrm{e}_{\mathrm{i}}^{\mathrm{BAU}}}\right)=\mathrm{p}+\mathrm{p}^{\prime} \cdot\left[\varepsilon_{\mathrm{i}}-\mathrm{e}_{\mathrm{i}}\right] \quad \forall \mathrm{i} \in \mathrm{S} \backslash \mathrm{C}
\end{array}
$$

Note that this general formulation allows for a cartel $\mathrm{C} \subseteq \mathrm{S}$ to be formed among the strategic players in $\mathrm{S}$ and that besides the cartel, individual strategic permit selling countries can exist. We make use of a generic algorithm to compute Cournot-Nash equilibria in the oligopoly model with competitive fringe. In every iteration step, the algorithm sequentially considers every noncompetitive player and chooses an emission strategy that maximizes - subject to the fringe's behavior summarized by expression (31) and the overall post-Kyoto emission ceiling (2) - its net benefits while keeping fixed the emission strategies of the other noncompetitive players. This procedures is repeated until the Euclidian distance between the nonfringe's emission vectors of two consecutive iterations is smaller than a given tolerance level.

In order to calculate the optimal bilateral contract variables the EU should offer to its contract parties, a separate welfare optimization problem is solved for the EU, taking as given the relevant first-order conditions for $\mathrm{F}$ and $\mathrm{S}$ and the participation constraints for the contract partners.

\subsection{Regions and Data}

Table 1 describes the regional aggregation used in the simulation model. Only countries that accepted quantified emission reductions according to Annex-B of the 1997 Kyoto Protocol (Annex- B countries) are included plus China. The choice of aggregation of these countries into regions was motivated more by arguments of similarity in economic development and emission efficiency of production rather than by political considerations.

\footnotetext{
${ }^{19}$ Subscript $\mathrm{C}$ refers to the sum of the corresponding variable over all cartel members.
} 
Table 1: regional aggregation

\begin{tabular}{|c|c|c|}
\hline abreviation & name & Composition \\
\hline EU15 & $\begin{array}{l}\text { Europe Union } 15 \\
\text { members }\end{array}$ & $\begin{array}{l}\text { Austria, Belgium, Denmark, Finland, France, } \\
\text { Germany, Greece, Ireland, Italy, Luxembourg, } \\
\text { Netherlands, Portugal, Spain, Sweden, UK }\end{array}$ \\
\hline CEU & Eastern Europe & $\begin{array}{l}\text { Bulgaria, Croatia, Cyprus, Czech Republic, } \\
\text { Estonia, Hungary, Latvia, Lithuania, Poland, } \\
\text { Romania, Slovakia, Slovenia }\end{array}$ \\
\hline OEU & Other Europe & Iceland, Malta, Norway and Switzerland \\
\hline RUS & Russia & \\
\hline UKR & Ukraine & \\
\hline CAN & Canada & \\
\hline JAP & Japan & \\
\hline AUS & Australia & \\
\hline NZL & New Zealand & \\
\hline CHN & China* & \\
\hline USA & $\begin{array}{l}\text { United States of } \\
\text { America }\end{array}$ & \\
\hline ROW & Rest of the World** & \\
\hline
\end{tabular}

* China is not an Annex-B country.

** Belarus, Kazachstan and Turkey are not included because their status in the Kyoto Protocol remains unclear.

Table 2 shows the basic data input for the model which consists of estimates of the cost function parameter and projected BAU emissions in the future. The projections were constructed using the aggregate growth rates in the United States Department of Energy (DoE) International Energy Outlook (IEO) 2005 (reference case, see http:/www.eia.doe.gov/oiaf/archive/ieo05/) and detailed data of individual countries GDP (purchasing power parity) and emissions of carbon dioxide from fossil fuel use taken from the World Resources Institute (WRI) Climate Analysis Indicator Tool (CAIT) (see http://cait.wri.org/). The cost parameters were estimated on a set of simulation runs with the GEM-E3 World general equilibrium model (see http://www.gem-e3.net for more detailed information $)^{20}$.

\footnotetext{
${ }^{20}$ We are grateful to Denise Van Regemorter (Center for Economic Studies, Katholieke Universiteit Leuven) for providing us with the necessary cost data to estimate the cost functions.
} 
Table 2: data input

\begin{tabular}{|l|c|c|c|c|c|c|c|c|c|}
\hline & E1990 & AAU\% & AAU & E2015 & gE & hot & Y2015 & gY & $\gamma$ \\
\hline EU15 & 4,085 & 74.9 & 3,060 & 4,261 & 0.17 & - & 12,987 & 2.30 & -258 \\
\hline CEU & 1,281 & 75.9 & 973 & 1,197 & -0.27 & - & 1,732 & 3.00 & -96 \\
\hline OEU & 104 & 80.5 & 84 & 115 & 0.40 & - & 516 & 2.30 & -448 \\
\hline RUS & 2,916 & 84.0 & 2,449 & 2,475 & -0.65 & - & 1,906 & 3.70 & -65 \\
\hline UKR & 926 & 81.1 & 751 & 675 & -1.26 & 11.31 & 442 & 4.90 & -65 \\
\hline JAP & 1,212 & 79.1 & 959 & 1,418 & 0.63 & - & 3,822 & 1.10 & -253 \\
\hline CAN & 649 & 84.2 & 546 & 964 & 1.60 & - & 1,176 & 2.30 & -188 \\
\hline AUS & 416 & 88.3 & 367 & 632 & 1.69 & - & 764 & 2.90 & -200 \\
\hline NZL & 65 & 112.3 & 73 & 95 & 1.50 & - & 118 & 2.90 & -200 \\
\hline CHN & 3,993 & 274.4 & 10,956 & 10,956 & 4.12 & - & 13,623 & 6.50 & -126 \\
\hline USA & 5,573 & 96.0 & 5,350 & 8,167 & 1.54 & - & 14,497 & 2.90 & -136 \\
\hline ROW & 17,048 & 204.6 & 34,881 & 34,881 & 2.90 & - & 25,965 & 5.30 & -153 \\
\hline KYOTO & 17,227 & 87.9 & 14,613 & 19,998 & 0.06 & - & 37,959 & 2.53 & - \\
\hline TOTAL & 38,268 & 165,33 & 63,267 & 65,836 & 2.19 & - & 77,547 & 3.99 & - \\
\hline
\end{tabular}

E1990: emissions 1990 of all 6 greenhouse gases $\mathrm{CO}_{2}, \mathrm{CH}_{4}, \mathrm{~N}_{2} \mathrm{O}, \mathrm{PFCs}, \mathrm{HFCs}, \mathrm{SF}_{6}$ including land use changes in million tonnes of $\mathrm{CO}_{2}$ equivalent; AAU\%: assigned amount units in \% of 1990 emissions computed taking into account the Bonn-Marrakesh agreements (using den Elzen and Both 2002) and 20\% additional reduction; AAU: assigned amount units in million tonnes of $\mathrm{CO}_{2}$ equivalent; E2015: projected emissions 2015 in million tonnes of $\mathrm{CO}_{2}$ equivalent; $\mathbf{g E}$ : average annual growth rate emissions between 1990 and 2015 in \%; hot air: difference between AAU and E2015 (only for regions for which AAU $\geq$ E2015) as \% of E2015; Y2015: projected GDP 2015 in billion US\$2000; gY: average annual growth rate GDP between 2003 and 2015 in \%; $\gamma$ : parameter marginal benefit of emission function.

E1990 was constructed from WRI-CAIT database and includes all six greenhouse gases covered by the 1997 Kyoto Protocol including emissions from land use changes. AAU and AAU\% were computed by combining E1990 with the individual commitments in Annex-B of the 1997 Kyoto Protocol and taking into account the Bonn-Marrakesh agreements (as in den Elzen and Both 2002) plus and additional reduction of $20 \%$. Hence, we assume that emission targets for the second commitment period 2013-2017 is $20 \%$ lower than during the first commitment period. The USA was treated differently, we assumed a reduction by $4 \%$ compared to 1990 emission levels. Notice that for this assumption only Ukraine has some limited amount of "hot air"" 2007 projections. The parameter $\gamma_{i}$ was estimated with OLS on a dataset of simulation results from the GEM-E3 World model. All emission data are expressed in million tonnes of $\mathrm{CO}_{2}$ equivalent and all GDP values are expressed in billion US\$ of 2000.

\footnotetext{
21 Theoretically speaking, non-fringe countries with "hot air", i.e. countries for which $\varepsilon_{\mathrm{r}}>\mathrm{e}_{\mathrm{r}}^{\mathrm{BAU}}$, might be tempted not to reduce their emissions and even to withhold some of their hot air permits in order to drive up the permit price. We will ignore this possibility since it is of little relevance to the simulation results in our case.
} 


\subsection{Results}

In this section we present results from the simulation model under different scenarios regarding market behavior and bilateral agreements. In a first subsection we discuss the references scenario of competitive international permit markets. In subsection two the outcome of the international permit market under noncompetitive behavior is reported. Subsection three describes the outcome of the market under optimal bilateral agreements offered by the EU. A detailed sensitivity analysis is reported in subsection four.

\subsubsection{Reference scenario}

Before comparing the different scenarios in detail, we first take a closer look at the reference scenario which assumes competitive emissions trading. Details of the reference scenario for all individual regions and countries can be found in Table 3. Assuming that all countries and regions, except for Rest of the World (ROW) act as price takers, the equilibrium permit price would amount to $25.16 \$$ per tonne of $\mathrm{CO}_{2}$. For that price, and given the BAU emission projections and benefit function parameters, four countries are net permit exporters: Central Europe (CEU), Russia (RUS), Ukraine (UKR) and China (CHN). In total, the Kyoto group reduces its emissions by $17.40 \%$ compared to BAU emissions in 2015. Total compliance costs for the group amount to about 65.255 million US\$ or $0.13 \%$ of their projected GDP in 2015. 
Table 3: Reference scenario: competitive permit market. ${ }^{22}$

\begin{tabular}{|l|c|c|c|c|c|c|c|c|c|}
\hline & AAU & $\mathbf{E}$ & $\mathbf{R}$ & $\mathbf{E X P}$ & MAC & AC & TRADE & TC & MUP \\
\hline EU15 & 72.84 & 90.70 & 9.30 & -18.88 & 25.16 & 4,905 & 20,244 & 25,149 & - \\
\hline CEU & 81.30 & 76.86 & 23.14 & 4.44 & 25.16 & 3,331 & $-1,336$ & 1,994 & - \\
\hline OEU & 72.82 & 94.54 & 5.46 & -21.72 & 25.16 & 78 & 627 & 706 & - \\
\hline RUS & 98.97 & 67.90 & 32.10 & 31.07 & 25.16 & 9,351 & $-19,346$ & $-9,995$ & - \\
\hline UKR & 111.31 & 67.90 & 32.10 & 43.40 & 25.16 & 2,549 & $-7,369$ & $-4,820$ & - \\
\hline JAP & 67.61 & 90.52 & 9.48 & -22.91 & 25.16 & 1,663 & 8,176 & 9,838 & - \\
\hline CAN & 56.65 & 87.49 & 12.51 & -30.84 & 25.16 & 1,484 & 7,479 & 8,963 & - \\
\hline AUS & 58.15 & 88.17 & 11.83 & -30.02 & 25.16 & 921 & 4,771 & 5,692 & - \\
\hline NZL & 77.34 & 88.17 & 11.83 & -10.83 & 25.16 & 138 & 258 & 397 & - \\
\hline CHN & 100 & 81.96 & 18.04 & 18.04 & 25.16 & 24,044 & $-49,736$ & $-25,692$ & - \\
\hline USA & 100 & 83.14 & 16.86 & -17.63 & 25.16 & 16,792 & 36,231 & 53,023 & - \\
\hline ROW & 100 & 100 & 0 & 0 & 0 & 0 & 0 & 0 & - \\
\hline F & 82.60 & 82.60 & 17.40 & 0 & 25.16 & 65,255 & 0 & 65,255 & - \\
\hline$\underline{\text { S }}$ & - & - & - & - & - & - & - & - & - \\
\hline WORLD & 91.82 & 91.82 & 8.18 & 0 & 10.64 & 65,255 & 0 & 65,255 & - \\
\hline
\end{tabular}

price: $25.16 \$$ tonne $\mathrm{CO}_{2}$

$$
\begin{aligned}
& \mathbf{F}=\{\text { EU15, CEU, OEU, RUS, UKR, JAP,CAN, AUS, NZL,CHN,USA }\} \\
& \underline{\mathbf{S}}=\varnothing
\end{aligned}
$$

As there are only four permit exporters in the reference competitive market scenario, concerns about market power seem justified. In Table 4 we calculate the Herfindahl-Hirschman index ${ }^{23}$ (HHI in the sequel) measure of market concentration for the international permit market in 2015.

\footnotetext{
${ }^{22}$ AAU: assigned amount units or initial emission permit allocation as \% of projected 2015 emissions; E: remaining emissions in 2015 as \% of projected 2015 emissions; R: emissions reduction as \% of projected 2015 emissions; EXP: net export of emissions permits (AAU-E) as \% of projected 2015 emissions; MAC: marginal emission reduction cost in $\mathrm{US}_{2000}$ per tonne of $\mathrm{CO}_{2} ; \mathbf{A C}$ : emission abatement costs in million US\$2000; TRADE: market value of net emissions permits trade (-p.EXP) in million US $\$_{2000}$; TC: total net cost (AC+TRADE) in million US $\$_{2000}$; mup: markup or difference in percent between MAC and price relative to price $((\mathbf{p}-\mathbf{M A C}) / \mathbf{p})$. F: set of fringe countries / regions and S: set of strategic (i.e. non price taking) market participants.

${ }^{23}$ The Herfindahl-Hirschman index equals the sum of squared market shares (in \%) of all market participants. It ranges between 0 (perfect competition) and 10.000 (monopoly). Markets with HHI in excess of 1.800 are considered to be concentrated and might raise antitrust concerns, see Cabral (2000).
} 
Table 4: permit market shares

\begin{tabular}{|l|c|c|c|c|c|c|}
\hline & $\begin{array}{c}\text { Initial } \\
\text { permit } \\
\text { allocation }\end{array}$ & $\%$ & $\begin{array}{c}\text { Permit } \\
\text { exports }\end{array}$ & \% & $\begin{array}{c}\text { Permits } \\
\text { imports }\end{array}$ & $\%$ \\
\hline EU15 & 3,060 & $12.0 \%$ & - & - & -805 & $26.0 \%$ \\
\hline CEU & 973 & $3.8 \%$ & 53 & $1.7 \%$ & - & - \\
\hline OEU & 84 & $0.3 \%$ & - & - & -25 & $0.8 \%$ \\
\hline RUS & 2,449 & $9.6 \%$ & 769 & $24.9 \%$ & - & - \\
\hline UKR & 751 & $2.9 \%$ & 293 & $9.5 \%$ & - & - \\
\hline JAP & 959 & $3.8 \%$ & - & - & -325 & $10.5 \%$ \\
\hline CAN & 546 & $2.1 \%$ & - & - & -297 & $9.6 \%$ \\
\hline AUS & 367 & $1.4 \%$ & - & - & -189 & $6.1 \%$ \\
\hline NZL & 73 & $0.3 \%$ & - & - & -10 & $0.3 \%$ \\
\hline CHN & 10,956 & $42.8 \%$ & 1,977 & $63.9 \%$ & - & - \\
\hline USA & 5,350 & $20.9 \%$ & - & - & 1,440 & $46.6 \%$ \\
\hline & & & & & & \\
\hline HHI & & 2,553 & & 4,799 & & 3,088 \\
\hline
\end{tabular}

Initial permits, permit exports and imports in million tonnes of $\mathrm{CO}_{2}$ equivalent.

Based on the shares in total amount of initial permits (first column in Table 4) we see that China (42.8\%) and USA (20.9\%) hold most of the permits. The implied HHI amounts to 2,553. However, as pointed out by Bode and Sharifi (2007), it makes not much sense to assess concentration in the permit market based on initial permit allocations only. One should look at equilibrium market shares which depend upon on a combination of the initial permit allocation, marginal abatement cost function parameters and BAU emissions. This is done in the other columns in Table 4 for permit exporters and importers separately. At the exporters' side, China (63.9\%) and Russia (24.9\%) account for most of the permit supply into the Kyoto market. The HHI on the exporters side is 4,799 , indicating very strong concentration. On the importers' side, the HHI is lower $(3,088)$ but it is still higher than the often used critical level of 1,800 . USA (46.6\%) accounts for almost half of all permit demand, followed by EU15 (26.0\%), Japan (10.5\%) and Canada $(9.6 \%)$. We conclude from this table that it is of particular importance to study non-competitive market behavior by China, Russia and Ukraine on the supply side of the international permit market.

\subsubsection{Scenario 1: noncompetitive permit market}

In this section we consider which outcome would arise in the absence of bilateral contracts when the major permit exporters behave non-competitively. As we consider three major 
strategic permit exporters Russia, Ukraine and China, the question is whether these suppliers would be able to form a stable cartel or not. In order to test for that, we compute all possible coalitions of the strategic players and we test which coalition is stable, in the sense of d'Aspremont et al. (1983). A cartel is said to be stable if it is both internally and externally stable. This means that no cartel member can improve its payoff by leaving the cartel, and no non-member can gain from joining the cartel. Table 5 reports the pays offs and stability properties for all possible combinations of cartel players.

Table 5: permit exporters' cartel stability analysis

\begin{tabular}{|c|c|c|c|c|c|c|c|c|}
\hline $\begin{array}{c}\text { cartel } \\
\text { key }\end{array}$ & Russia & Ukraine & China & total & price & IS & ES & stability \\
\hline $\mathbf{0 0 0}$ & 15,505 & 7,169 & 33,044 & 55,718 & 32.69 & 1 & 1 & 1 \\
\hline $\mathbf{0 1 1}$ & 16,788 & 6,479 & 34,090 & 57,357 & 34.09 & 0 & 0 & 0 \\
\hline $\mathbf{1 0 1}$ & 14,209 & 8,391 & 36,238 & 58,838 & 36.16 & 0 & 0 & 0 \\
\hline $\mathbf{1 1 0}$ & 15,648 & 7,041 & 34,294 & 56,983 & 33.34 & 0 & 1 & 0 \\
\hline $\mathbf{1 1 1}$ & 14,954 & 7,298 & 38,114 & 60,366 & 38.70 & 0 & 1 & 0 \\
\hline competitive & 9,995 & 4,820 & 25,692 & 40,507 & 25.16 & - & - & - \\
\hline
\end{tabular}

cartel key: binary key denoting membership of cartel, Russia, Ukraine and China: payoff in million US\$, total: sum of all three players' payoff, price: equilibrium market price, IS: internal stability, 1 if no cartel member can improve itself by leaving the cartel, ES: external stability, 1 if no non-member can improve itself by joining the cartel, stability: intersection of IS and ES. The cell shading indicates membership of the cartel.

Table 5 reveals that non-competitive market behavior can lead to sharp price increases. The price of permits under Cournot competition would amount to $32.69 \$$ versus $25.16 \$$ if the market were competitive, i.e. an increase by about $23 \%$. The stability analysis shows that there does not exist an internally stable cartel of permit exporters (except for the trivial case of no collusion " 000 " which is internally stable by definition). If they would behave jointly as a cartel ("111"), they would achieve the highest joint payoff because they can increase the market price to $€ 38.70$. However, this coalition is not internally stable because Ukraine can gain from leaving. It achieves a payoff equal to 8,391 in " 101 " versus only 7,298 in " 111 ".24 This stability analysis leads us to the conclusion that the relevant outside options that the EU should take into account while negotiating with its potential contract partners are the payoffs under the Cournot scenario " 000 ". No contract partner (or group of contract partners) can

\footnotetext{
${ }^{24}$ One might argue that it is not a good idea of Ukraine to deviate because coalition " 101 " is not internally stable. The initial deviation by Ukraine will trigger a further deviation by Russia from " 101 " leading to the Cournot case " 000 ". Under that scenario, Ukraine is worse off than under the full cartel "111". Hence, if Ukraine is "farsighted", it should not deviate from the grand cartel. This argument is correct but note that Russia has a clear incentive, even if it is "farsighted", to deviate from the grand cartel since it is better off in the Cournot outcome than in " 111 ".
} 
claim more than their payoffs in the Cournot scenario because no permit sellers' cartel is stable.

\subsubsection{Optimal choice of contract partners}

In the final step of the analysis, the EU should try to find the best contract partner, or group of partners, taking into account their relevant participation constraints. Table 6 lists all possible combinations of partnerships. The first three lines refer to partnerships with only one country, the remaining lines refer to contracts with groups of permit exporters. The objective for the $\mathrm{EU}$ is to have as low compliance costs as possible, hence the last option of offering a contract to all outsiders (line "111"), is preferred by the EU. Note that this contract yields a payoff of 29,962 to the EU which is better than $-32,115$ that EU would achieve when it did not offer any contracts to permit exporters and the permit market would revert to the Cournot scenario. The EU gains because it can lower its compliance costs by $6.07 \%$ compared to the Cournot permit market without bilateral contracts. However, this scenario is one under which the equilibrium price is higher than in the no contract case. Hence, the EU27, Russia, Ukraine and China are forming jointly a sellers cartel and financial transfers flow towards EU27. As we dismissed this type of outcome as unrealistic in the theoretical part of the paper, we restrict attention to those outcomes under which equilibrium prices are lower with contracts compared to no contracts. This corresponds to scenarios that are not shaded in Table 6.

Table 6: EU's contract partner choice problem

\begin{tabular}{|c|c|c|c|c|c|}
\hline $\begin{array}{c}\text { Partnership } \\
\text { key }\end{array}$ & EU27 & Russia & Ukraine & China & price \\
\hline $\mathbf{0 0 1}$ & $-30,724$ & 13,044 & 6,229 & 33,044 & 29.86 \\
\hline $\mathbf{0 1 0}$ & $-32,374$ & 15,316 & 7,169 & 32,907 & 32.48 \\
\hline $\mathbf{1 0 0}$ & $-31,944$ & 15,505 & 6,832 & 31,241 & 31.60 \\
\hline $\mathbf{1 1 0}$ & $-32,213$ & 15,505 & 7,169 & 32,043 & 32.03 \\
\hline $\mathbf{1 0 1}$ & $-31,700$ & 15,505 & 7,794 & 33,044 & 33.75 \\
\hline $\mathbf{0 1 1}$ & $-32,538$ & 15,404 & 7,169 & 33,044 & 31.13 \\
\hline $\mathbf{1 1 1}$ & $-29,962$ & 15,505 & 7,169 & 33,044 & 36.34 \\
\hline
\end{tabular}

Partnership key: binary key denoting which partner is offered a contract, price: equilibrium market price assuming optimized contracts. Shaded cells refer to scenarios in which the equilibrium price with bilateral contracts is higher than in the no contract case.

The EU has a clear advantage from offering a bilateral contract to China only (001). China is equally well off as in the Cournot scenario because its individual participation constraint was taken into account when constructing the optimal bilateral contract. The EU gains $4.33 \%$ from the contract compared to the Cournot market outcome. 


\subsubsection{Sensitivity analysis}

We conducted an extensive sensitivity analysis regarding the crucial parameters of the simulation model, i.e. the slope of the marginal benefit functions and the growth rates of emissions and GDP. In Table 7 we report the most important outcome variables of the sensitivity analysis. The first sensitivity analysis (1) assumes that all countries' benefit function parameter is $50 \%$ higher than in the reference run of the model, the second sensitivity analysis (2) assumes they are 50\% lower. In the third exercise (3), growth rates of GDP and carbon emissions for the USA were lowered by $50 \%$. For the fourth sensitivity analysis (4), we assumed that all regions' growth rates of GPD and emissions are $50 \%$ below the levels in the reference run.

Table 7: Sensitivity analysis

\begin{tabular}{|c|c|c|c|c|c|}
\hline & (0) & (1) & (2) & (3) & (4) \\
\hline & $\begin{array}{l}\text { Reference } \\
\text { run }\end{array}$ & $\begin{array}{c}\text { Higher } \\
\text { marginal } \\
\text { benefit }\end{array}$ & $\begin{array}{c}\text { Lower } \\
\text { marginal } \\
\text { benefits }\end{array}$ & $\begin{array}{l}\text { Lower USA } \\
\text { growth rates }\end{array}$ & $\begin{array}{l}\text { Lower growth } \\
\text { rates all regions }\end{array}$ \\
\hline price & 29.86 & 44.79 & 14.93 & 24.90 & 23.05 \\
\hline gain EU & $4.33 \%$ & $4.33 \%$ & $4.33 \%$ & $5.71 \%$ & $8.37 \%$ \\
\hline $\begin{array}{l}\text { contract } \\
\text { partner }\end{array}$ & $\mathrm{C}$ & $\mathrm{C}$ & $\mathrm{C}$ & $\mathrm{C}$ & $\mathrm{C}$ \\
\hline $\begin{array}{c}\text { stable } \\
\text { cartels }\end{array}$ & none & none & none & None & “101" \\
\hline
\end{tabular}

Price: equilibrium market price assuming optimized contracts, gain EU: cost reduction compared to the noncompetitive market without contracts (Cournot outcome or stable cartel outcome, if any), contract partner: preferred contract partner for $\mathrm{EU}(\mathrm{R}=\mathrm{Russia}, \mathrm{U}=\mathrm{Ukraine}, \mathrm{C}=\mathrm{China})$, stable cartels: stable cartel of permit exporters in absence of contracts (none means that the market reverts to Cournot situation).

If we change the slope of the marginal benefit of emissions function for all regions in the same way (columns 1 and 2), than the qualitative results are the same as in the reference run (0). No stable cartel of permit sellers can form and the EU should negotiate a bilateral contract with China only. The relative gain for the EU from the contract deal remains the same as in the reference run: a total compliance cost reduction of $4.33 \%$. Although the relative gain is equal, there are pronounced differences between the scenarios as can be seen from the equilibrium price differences. When we lower the GDP and emissions growth rates of USA only (scenario 3), we still have no stable cartel of permit sellers and the preferred contract partner for the EU is again only China. The cost savings for the EU are slightly higher (5.71\%) compared to the reference run. When all growth rates for all regions are lower by $50 \%$ (global persistent crisis scenario 4), a stable permit selling cartel by Russia and China 
emerges. Taking this cartel into account for the participation constraints, it is optimal for the EU to offer a contract to China only. This optimal contract leads to a compliance cost reduction by $8.37 \%$, higher than in the reference run. Intuitively, the fact that a stable cartel of permit sellers emerges has a strongly negative impact on the compliance cost of the EU through the sharp permit price increase compared to the Cournot situation. Hence, the EU has more to gain from bilateral contracts with strategic permit sellers in this scenario.

\section{Concluding remarks}

In this paper, we have shown theoretically how a group of net buyers of permits (the EU countries) benefits from designing bilateral agreements regarding a minimum amount of permit sales with large permit sellers. Such agreements enable the EU to act strategically in the permit market on behalf of its member states, although each member state behaves as a price taker in the permit market.

We assumed that the contract partners would have acted strategically in the permit market in the absence of permit trade contracts. However, this assumption is not crucial for our conclusion. Even if the contract partners did not intend to act strategically in the permit market, the group of net buyers would benefit from offering contracts which induces their partners to alter their strategy compared to the scenario without bilateral contracts. We demonstrated that a set of optimal contracts leads to a situation where the marginal benefits of emissions for the contract parties deviate from the market permit price. Hence, there is also a potential gain for the EU countries if they make bilateral agreements with several price-taking countries by inducing them to increase their permits sales volume. However, the transaction costs of designing and implementing many bilateral contracts may outweigh the benefits from lower permit price.

In the numerical part of the paper we considered a possible follow-up agreement to the Kyoto protocol with emission targets for the original member of the Kyoto club 20\% lower than during the first commitment period. China was assumed to obtain an initial allocation of permits equal to their expected BaU-emissions if it joined the agreement. Based on these permit allocations, and on estimates of BAU emission levels and marginal abatement costs, we found that it is of particular importance to study non-competitive market behavior by China, Russia and Ukraine on the supply side of the international permit market.

The numerical simulations of the post-Kyoto permit market showed that, by offering a deal to China, the EU can cut its net compliance costs significantly, even after accounting for the 
financial transfer needed to satisfy China's voluntary participation constraint. This result was shown to be stable for various alternative parameterizations of the simulation model.

\section{References:}

Barrett, S. (1999), A theory of full international cooperation, Journal of Theoretical Politics 11(4): 519-541.

Bernard, A., Haurie, A., Viellec, M. and Viguier, L. (2008), A two-level dynamic game of carbonemission trading between Russia, China, and Annex B countries, Journal of Economic Dynamics and Control 32: 1830-1856.

Bréchet, T., Eyckmans, J., Gerard, F; Marbaix, P., Tulkens, H. and van Ypersele, J.-P. (2009), The impact of the unilateral EU commitment on the stability of international climate agreements, mimeo Université Catholique de Louvain.

Bode, S. and O. Sharifi (2007), Market shares and dominant market positions in the case of emissions trading, Carbon and Climate Law Review 2(2): 105-118.

Bohm, P. (2002), "Improving Cost-effectiveness and Facilitating Participation of Developing Countries in International Emission Trading", International Environmental Agreements: Politics, Law and Economics 3: 261-275.

Buchner, B. and C. Carraro (2003), China and the Evolution of the Present Climate Regime, Working Paper, FEEM, Milan.

Cabral, L.M.B. (2000), Introduction to Industrial Organization (The MIT Press, Cambridge, Mass. and London UK)

Criqui, P., Mima, S. and Viguier, L. (1999), Marginal abatement costs of $\mathrm{CO}_{2}$ emission reductions, geographical flexibility and concrete ceilings: an assessment using the POLES model, Energy Policy 27: 585-601.

Böhringer, C. (2002), Climate Politics from Kyoto to Bonn: From Little to Nothing?, The Energy Journal 23: 51-73.

Chander, P. and Tulkens, H. (1995), A core-theoretic solution for the design of cooperative agreements on transfrontier pollution, International Tax and Public Finance 2: 279-293.

d'Aspremont, C., A. Jacquemin, J. J. Gabszewicz and J. A. Weymark (1983), On the Stability of Collusive Price Leadership, Canadian Journal of Economics 16(1): 17-25.

den Elzen, M.G.J. and de Moor, A.P.G. (2002), Analyzing the Kyoto Protocol under the Marrakesh Accords: Economic Efficiency and Environmental Effectiveness, Ecological Economics 43: 141-158.

den Elzen, M.G.J. and Both, S. (2002), Modelling emissions trading and abatement costs in FAIR 1.1, case study: the Kyoto Protocol under the Bonn-Marrakesh Agreement, RIVM report $728001021 / 2002$.

Ellerman, A.D. and I. S. Wing (2000), Supplemantarity: An Invitation for Monopsony, The Energy Journal 21(4): 29-59.

Eyckmans, J., Van Regemorter, D. and van Steenberghe, V. (2005), Kyoto-Permit Prices and Compliance Costs: An Analysis with MacGEM, in : Willems, B., Eyckmans, J. and Proost, 
S. (eds.), Economic Aspects of Climate Change Policy, A European and Belgian Perspective (ACCO, Leuven-Voorburg), chapter V, 45-55.

Finus, M. (2003), Stability and Design of International Environmental Agreements: The Case of Transboundary Pollution. In: Folmer, H. and T. Tietenberg (eds), International Yearbook of Environmental and Resource Economics 2003/4 (Edward Elgar, Cheltenham, UK), chapter 3, 82-158.

Fischer, C. (2005), Project-based Mechanisms for Emission Reductions: Balancing Trade-offs with Baselines, Energy Policy 33, 1807-1823.

Golombek, R. and M. Hoel (2006), Second-Best Climate Agreements and Technology Policy, Advances in Economic Analysis \& Policy 6(1) article 1.

Hagem, C. and B. Holtsmark (2001), From Small to Insignificant: Climate Impact of the Kyoto Protocol with and without the US, CICERO Policy Note 2001-01, Oslo.

Hahn, R. W. (1984), Market Power and Transferable Property Rights, The Quarterly Journal of Economics 99(4): 753-765.

Neuhoff, K., Keats Martinez, K., Sato, M., (2006), Allocation, incentives and distortions: the impact of EU ETS emissions allowance allocations to the electricity sector, Climate Policy 6(1), 73-91.

Repetto, R. (2001), The Clean Development Mechanism: Institutional breakthrough or institutional nightmare?, Policy Science 34: 303-327.

Sager, J. (2003), An analysis with the CERT model of the FSU market power in the carbon emissions trading market, Environmental Modeling and Assessment 8: 219-238.

Stewart, R.B. and J.B. Wiener (2003), Reconstructing Climate Policy (American Enterprise Institute for Public Policy Research AEI, Washington DC)

Weyant, J. (ed.) (1999), The Costs of the Kyoto Protocol: a Multi-Model Evaluation, The Energy Journal, Special Issue, International Association for Energy Economics.

Weyant, J. and J. Hill (1999), Introduction and Overview, in: Weyant, J.(ed) The Costs of the Kyoto Protocol: a Multi-Model Evaluation, The Energy Journal, Special Issue, International Association for Energy Economics. 


\section{Appendix}

\section{Proof of proposition 1}

As $\mathrm{B}_{\mathrm{EU}}$ denotes the EU's joint benefit of the sum of emission from all the EU-countries when emissions from all EU countries are given by first-order conditions (5), it follows that $\tilde{\mathrm{p}}=\mathrm{B}_{\mathrm{i}}^{\prime}=\mathrm{B}_{\mathrm{EU}}^{\prime} \quad \forall \mathrm{i} \in \mathrm{EU}$. When the contract partners' supply of permits is set in the first stage, by the determination of $\sum_{c \in C P} \bar{e}_{c}$, the other large sellers become Stackelberg followers in the permit market in the second stage. We see from (7), (8), (13) and (21) that $\tilde{\mathrm{p}}=\tilde{\mathrm{p}}\left(\sum_{\mathrm{c} \in \mathrm{CP}} \overline{\mathrm{e}}_{\mathrm{c}}\right)=\mathrm{p}\left(\varepsilon_{\mathrm{K}}-\left[\tilde{\mathrm{e}}_{\mathrm{RS}}\left(\sum_{\mathrm{c} \in \mathrm{CP}} \overline{\mathrm{e}}_{\mathrm{c}}\right)+\sum_{\mathrm{c} \in \mathrm{CP}} \overline{\mathrm{e}}_{\mathrm{c}}\right]\right)$. Hence $\frac{\partial \tilde{\mathrm{p}}}{\partial \overline{\mathrm{e}}_{\mathrm{c}}}=\mathrm{p}^{\prime} \cdot\left[1+\frac{\partial \tilde{\mathrm{e}}_{\mathrm{RS}}}{\partial \overline{\mathrm{e}}_{\mathrm{c}}}\right]$. By assumption, $\mathrm{p}^{\prime}<0$ (see eq. (7)) and $-1<\frac{\partial \tilde{\mathrm{e}}_{\mathrm{RS}}}{\partial \overline{\mathrm{e}}_{\mathrm{c}}}<0$ (see footnote 9), such that $\frac{\partial \tilde{\mathrm{p}}}{\partial \overline{\mathrm{e}}_{\mathrm{c}}}<0$. If EU and the contract partners jointly are are net buyers (sellers) of permits, $\left[\sum_{\mathrm{c} \in \mathrm{CP}} \varepsilon_{\mathrm{c}}+\varepsilon_{\mathrm{EU}}-\left[\mathrm{e}_{\mathrm{EU}}+\sum_{\mathrm{c} \in \mathrm{CP}} \overline{\mathrm{e}}_{\mathrm{c}}\right]\right]<$ $0(>0)$, the left hand side of (25) is negative (positive), which implies that $\left(\mathrm{B}_{\mathrm{EU}}^{\prime}-\mathrm{B}_{\mathrm{c}}^{\prime}\right)<0$ $(>0)$.

\section{Proof of proposition 2}

We see from (25), that $\tilde{p}-B_{c}^{\prime}$ is equal across contract partners as the left hand side is equal across all contract partners.

\section{Proof of proposition 3}

The first order condition for each of the contract partners' emissions under the optimal contract given by (25) can be rearranged to:

$$
\mathrm{B}_{\mathrm{c}}^{\prime}\left(\overline{\mathrm{e}}_{\mathrm{c}}\right)=\mathrm{p}\left(\varepsilon_{\mathrm{K}}-\left[\tilde{\mathrm{e}}_{\mathrm{RS}}\left(\sum_{\mathrm{c} \in \mathrm{CP}} \overline{\mathrm{e}}_{\mathrm{c}}\right)+\sum_{\mathrm{c} \in \mathrm{CP}} \overline{\mathrm{e}}_{\mathrm{c}}\right]\right)+\mathrm{p}^{\prime} \cdot\left[1+\frac{\partial \tilde{\mathrm{e}}_{\mathrm{RS}}}{\partial \overline{\mathrm{e}}_{\mathrm{c}}}\right] \cdot\left[\sum_{\mathrm{c} \in \mathrm{CP}} \varepsilon_{\mathrm{c}}+\varepsilon_{\mathrm{EU}}-\left[\mathrm{e}_{\mathrm{EU}}+\sum_{\mathrm{c} \in \mathrm{CP}} \overline{\mathrm{e}}_{\mathrm{c}}\right]\right](\mathrm{A}
$$

Let $\mathrm{e}_{\mathrm{c}}^{*}$ denote the emissions from the contract partners which satisfy (10) (the non-contract outcome) with equality. $e_{c}^{*}$ can only satisfy both (10) and (A.1) if and only if:

$$
\mathrm{p}^{\prime} \cdot\left[1+\frac{\partial \mathrm{e}_{\mathrm{RS}}}{\partial \mathrm{e}_{\mathrm{c}}^{*}}\right] \cdot\left[\sum_{\mathrm{c} \in \mathrm{CP}} \varepsilon_{\mathrm{c}}+\varepsilon_{\mathrm{EU}}-\left[\mathrm{e}_{\mathrm{EU}}+\sum_{\mathrm{c} \in \mathrm{CP}} \overline{\mathrm{e}}_{\mathrm{c}}^{*}\right]\right]=\mathrm{p}^{\prime} \cdot\left[\varepsilon_{\mathrm{c}}-\mathrm{e}_{\mathrm{c}}^{*}\right]
$$

(Note that the price $\mathrm{p}$ is identical both with and without contracts for $\mathrm{e}_{\mathrm{c}}=\mathrm{e}_{\mathrm{c}}^{*} \quad \forall \mathrm{c} \in \mathrm{CP}$ ) 
We have assumed that the second order conditions for the maximization problems are always satisfied. Hence, the $e_{c}$ which satisfies (A.1) must be lower than $e_{c}^{*}$ if:

$$
\mathrm{p}^{\prime} \cdot\left[1+\frac{\partial \mathrm{e}_{\mathrm{RS}}}{\partial \mathrm{e}_{\mathrm{c}}^{*}}\right] \cdot\left[\sum_{\mathrm{c} \in \mathrm{CP}} \varepsilon_{\mathrm{c}}+\varepsilon_{\mathrm{EU}}-\left[\mathrm{e}_{\mathrm{EU}}+\sum_{\mathrm{c} \in \mathrm{CP}} \overline{\mathrm{e}}_{\mathrm{c}}^{*}\right]\right]>\mathrm{p}^{\prime} \cdot\left[\varepsilon_{\mathrm{c}}-\mathrm{e}_{\mathrm{c}}^{*}\right]
$$

And the $e_{c}$ which satisfies (A.1) must be higher than $e_{c}^{*}$ if:

$$
\mathrm{p}^{\prime} \cdot\left[1+\frac{\partial \mathrm{e}_{\mathrm{RS}}}{\partial \mathrm{e}_{\mathrm{c}}^{*}}\right] \cdot\left[\sum_{\mathrm{c} \in \mathrm{CP}} \varepsilon_{\mathrm{c}}+\varepsilon_{\mathrm{EU}}-\left[\mathrm{e}_{\mathrm{EU}}+\sum_{\mathrm{c} \in \mathrm{CP}} \overline{\mathrm{e}}_{\mathrm{c}}^{*}\right]\right]<\mathrm{p}^{\prime} \cdot\left[\varepsilon_{\mathrm{c}}-\mathrm{e}_{\mathrm{c}}^{*}\right]
$$

We know that (A.3) is satisfied if the EU and its contracts partner are net buyers as the left hand side of (A.3) in that case is positive (recall that $-1<\frac{\partial \tilde{\mathrm{e}}_{\mathrm{RS}}}{\partial \overline{\mathrm{e}}_{\mathrm{c}}}<0$ (see footnote 9) and $\mathrm{p}^{\prime}<0$ ), whereas the right hand side is negative (the contract partners are assumed to be sellers, that is $\left[\varepsilon_{\mathrm{c}}-\mathrm{e}_{\mathrm{c}}^{*}\right]>0$.

If the EU and its contract partners are net sellers, $\left[\sum_{\mathrm{c} \in \mathrm{CP}} \varepsilon_{\mathrm{c}}+\varepsilon_{\mathrm{EU}}-\left[\mathrm{e}_{\mathrm{EU}}+\sum_{\mathrm{c} \in \mathrm{CP}} \overline{\mathrm{e}}_{\mathrm{c}}^{*}\right]\right]>0$, and we cannot in general say whether (A.3) or (A.4) is satisfied. However, we know that if the EU has only one contract partner, (A.3) holds as $\mathrm{p}^{\prime} \cdot\left[1+\frac{\partial \mathrm{e}_{\mathrm{RS}}}{\partial \mathrm{e}_{\mathrm{c}}^{*}}\right] \cdot\left[\varepsilon_{\mathrm{c}}+\varepsilon_{\mathrm{eu}}-\left[\mathrm{e}_{\mathrm{eu}}+\mathrm{e}_{\mathrm{c}}^{*}\right]\right]>\mathrm{p}^{\prime} \cdot\left[\varepsilon_{\mathrm{c}}-\mathrm{e}_{\mathrm{c}}^{*}\right]$ since $0<\left[1+\frac{\partial \mathrm{e}_{\mathrm{RS}}}{\partial \mathrm{e}_{\mathrm{c}}^{*}}\right]<1$ (see footnote 9), and $\left[\varepsilon_{\mathrm{eu}}-\mathrm{e}_{\mathrm{eu}}\right]<0$, as EU countries are assumed be net buyer of permits. Hence, if follows from the second-order condition for the maximization problem that the emissions of the contract partner must be larger than $\mathrm{e}_{\mathrm{c}}^{*}$. Furthermore, since $-1<\frac{\partial \tilde{\mathrm{e}}_{\mathrm{RS}}}{\partial \overline{\mathrm{e}}_{\mathrm{c}}}<0$, total supply of permits is larger under the bilateral contracts scenarios than in the absence of such contracts, leading to a lower equilibrium permit price. 


\section{CESifo Working Paper Series}

for full list see www.cesifo-group.org/wp

(address: Poschingerstr. 5, 81679 Munich, Germany, office@cesifo.de)

2745 Bruno S. Frey and Paolo Pamini, Making World Heritage Truly Global: The Culture Certificate Scheme, August 2009

2746 Frank N. Caliendo, Is Social Security behind the Collapse of Personal Saving?, August 2009

2747 Caterina Liesegang and Marco Runkel, Corporate Income Taxation of Multinationals and Fiscal Equalization, August 2009

2748 Chrysovalantou Milliou and Apostolis Pavlou, Upstream Horizontal Mergers and Efficiency Gains, August 2009

2749 Rüdiger Pethig and Christian Wittlich, Interaction of Carbon Reduction and Green Energy Promotion in a Small Fossil-Fuel Importing Economy, August 2009

2750 Kai Carstensen, Oliver Hülsewig and Timo Wollmershäuser, Monetary Policy Transmission and House Prices: European Cross-country Evidence, August 2009

2751 Olaf Posch, Explaining Output Volatility: The Case of Taxation, August 2009

2752 Beatrice Scheubel, Daniel Schunk and Joachim Winter, Don't Raise the Retirement Age! An Experiment on Opposition to Pension Reforms and East-West Differences in Germany, August 2009

2753 Daniel G. Arce, Dan Kovenock and Brian Roberson, Suicide Terrorism and the Weakest Link, August 2009

2754 Mario Larch and Wolfgang Lechthaler, Comparative Advantage and Skill-Specific Unemployment, August 2009

2755 Horst Raff and Nicolas Schmitt, Buyer Power in International Markets, August 2009

2756 Seppo Kari, Hanna Karikallio and Jukka Pirttilä, The Impact of Dividend Taxation on Dividends and Investment: New Evidence Based on a Natural Experiment, August 2009

2757 Mirco Tonin and Michael Vlassopoulos, Disentangling the Sources of Pro-social Behavior in the Workplace: A Field Experiment, August 2009

2758 Nicole Grunewald and Inmaculada Martínez-Zarzoso, Driving Factors of Carbon Dioxide Emissions and the Impact from Kyoto Protocol, August 2009

2759 Yu-Fu Chen and Michael Funke, Booms, Recessions and Financial Turmoil: A Fresh Look at Investment Decisions under Cyclical Uncertainty, August 2009 
2760 Jan-Egbert Sturm and Jakob de Haan, Does Central Bank Communication really Lead to better Forecasts of Policy Decisions? New Evidence Based on a Taylor Rule Model for the ECB, August 2009

2761 Larry Karp, Sacrifice, Discounting and Climate Policy: Five Questions, August 2009

2762 Marianna Belloc and Samuel Bowles, International Trade, Factor Mobility and the Persistence of Cultural-Institutional Diversity, August 2009

2763 Charles Noussair and Fangfang Tan, Voting on Punishment Systems within a Heterogeneous Group, August 2009

2764 Birgit Bednar-Friedl and Karl Farmer, Internationally Coordinated Emission Permit Policies: An Option for Withdrawers from the Kyoto Protocol?, August 2009

2765 Pierre M. Picard and David E. Wildasin, Labor Market Pooling, Outsourcing and Labor Contracts, August 2009

2766 Stefan Voigt and Lorenz Blume, The Economic Effects of Federalism and Decentralization - A Cross-Country Assessment, August 2009

2767 David S. Jacks, Christopher M. Meissner and Dennis Novy, Trade Booms, Trade Busts, and Trade Costs, August 2009

2768 Mario Jametti and Thomas von Ungern-Sternberg, Hurricane Insurance in Florida, August 2009

2769 Alessandro Balestrino, Kind of Black: The Musicians' Labour Market in Italy, August 2009

2770 Yosr Abid Fourati and Cathal O’Donoghue, Eliciting Individual Preferences for Pension Reform, August 2009

2771 Christian Breuer and Chang Woon Nam, VAT on Intra-Community Trade and Bilateral Micro Revenue Clearing in the EU, August 2009

2772 Choudhry Tanveer Shehzad, Jakob De Haan and Bert Scholtens, Growth and Earnings Persistence in Banking Firms: A Dynamic Panel Investigation, August 2009

2773 Erdal Yalcin, Uncertain Productivity Growth and the Choice between FDI and Export, August 2009

2774 Klaus Abberger, Wolfgang Nierhaus and Shynar Shaikh, Findings of the Signal Approach for Financial Monitoring in Kazakhstan, September 2009

2775 Sascha O. Becker, Francesco Cinnirella and Ludger Woessmann, The Trade-off between Fertility and Education: Evidence from before the Demographic Transition, September 2009 
2776 Thomas Aronsson and Erkki Koskela, Optimal Income Taxation, Outsourcing and Policy Cooperation in a Dynamic Economy, September 2009

2777 Joel Slemrod, Old George Orwell Got it Backward: Some Thoughts on Behavioral Tax Economics, September 2009

2778 Cagri Seda Kumru and Athanasios C. Thanopoulos, Social Security Reform and Temptation, September 2009

2779 Alessandro Bucciol and Roel M. W. J. Beetsma, Inter- and Intra-generational Consequences of Pension Buffer Policy under Demographic, Financial and Economic Shocks, September 2009

2780 Eduardo Strube and Marcelo Resende, Complementarity of Innovation Policies in the Brazilian Industry: An Econometric Study, September 2009

2781 Henry Tulkens and Vincent van Steenberghe, "Mitigation, Adaptation, Suffering": In Search of the Right Mix in the Face of Climate Change, September 2009

2782 Maria L. Loureiro, Anna Sanz-de-Galdeano and Daniela Vuri, Smoking Habits: Like Father, Like Son, Like Mother, Like Daughter, September 2009

2783 Momi Dahan, Tehila Kogut and Moshe Shalem, Do Economic Policymakers Practice what they Preach? The Case of Pension Decisions, September 2009

2784 Eytan Sheshinski, Uncertain Longevity and Investment in Education, September 2009

2785 Nannette Lindenberg and Frank Westermann, How Strong is the Case for Dollarization in Costa Rica? A Note on the Business Cycle Comovements with the United States, September 2009

2786 Leif Danziger, Noncompliance and the Effects of the Minimum Wage on Hours and Welfare in Competitive Labor Markets, September 2009

2787 Gerlinde Fellner, Rupert Sausgruber and Christian Traxler, Testing Enforcement Strategies in the Field: Legal Threat, Moral Appeal and Social Information, September 2009

2788 Gabriel J. Felbermayr, Mario Larch and Wolfgang Lechthaler, Unemployment in an Interdependent World, September 2009

2789 Sebastian G. Kessing, Federalism and Accountability with Distorted Election Choices, September 2009

2790 Daniel Gros, Global Welfare Implications of Carbon Border Taxes, September 2009

2791 Louis N. Christofides, Michael Hoy and Ling Yang, The Gender Imbalance in Participation in Canadian Universities (1977-2005), September 2009

2792 Jan K. Brueckner and Robert W. Helsley, Sprawl and Blight, September 2009 
2793 Vidar Christiansen and Stephen Smith, Externality-correcting Taxes and Regulation, September 2009

2794 John Beirne, Guglielmo Maria Caporale, Marianne Schulze-Ghattas and Nicola Spagnolo, Global and Regional Spillovers in Emerging Stock Markets: A Multivariate GARCH-in-mean Analysis, September 2009

2795 Rüdiger Pethig and Frieder Kolleß, Asymmetric Capital-Tax Competition, Unemployment and Losses from Capital Market Integration, September 2009

2796 Ngo Van Long, Horst Raff and Frank Stähler, Innovation and Trade with Heterogeneous Firms, September 2009

2797 Margit Osterloh and Bruno S. Frey, Research Governance in Academia: Are there Alternatives to Academic Rankings?, September 2009

2798 Thiess Buettner and Clemens Fuest, The Role of the Corporate Income Tax as an Automatic Stabilizer, September 2009

2799 Annette Alstadsæter, Measuring the Consumption Value of Higher Education, September 2009

2800 Peter Friedrich, Chang Woon Nam and Janno Reiljan, Local Fiscal Equalization in Estonia: Is a Reform Necessary?, September 2009

2801 Evžen Kočenda and Jan Hanousek, State Ownership and Control in the Czech Republic, September 2009

2802 Michael Stimmelmayr, Wage Inequality in Germany: Disentangling Demand and Supply Effects, September 2009

2803 Biswa N. Bhattacharyay, Towards a Macroprudential Surveillance and Remedial Policy Formulation System for Monitoring Financial Crisis, September 2009

2804 Margarita Katsimi, Sarantis Kalyvitis and Thomas Moutos, "Unwarranted" Wage Changes and the Return on Capital, September 2009

2805 Christian Lessmann and Gunther Markwardt, Aid, Growth and Devolution, September 2009

2806 Bas Jacobs and Dirk Schindler, On the Desirability of Taxing Capital Income to Reduce Moral Hazard in Social Insurance, September 2009

2807 Hans Gersbach and Noemi Hummel, Climate Policy and Development, September 2009

2808 David E. Wildasin, Fiscal Competition for Imperfectly-Mobile Labor and Capital: A Comparative Dynamic Analysis, September 2009

2809 Johan Eyckmans and Cathrine Hagem, The European Union's Potential for Strategic Emissions Trading through Minimal Permit Sale Contracts, September 2009 